\title{
Social-ecological drivers and impacts of invasion-related regime shifts: consequences for ecosystem services and human wellbeing
}

\author{
Ross T. Shackleton $^{\mathrm{a}, \mathrm{b}, *}$, Reinette Biggs ${ }^{\mathrm{c}, \mathrm{d}}$, David M. Richardson ${ }^{\mathrm{a}}$, Brendon M.H. Larson ${ }^{\mathrm{b}}$ \\ a Centre for Invasion Biology, Department of Botany and Zoology, Stellenbosch University, Matieland, 7602, South Africa \\ ${ }^{\mathrm{b}}$ School of Environment, Resources and Sustainability, University of Waterloo, Waterloo, Ontario N2L3G1, Canada \\ ${ }^{\mathrm{c}}$ Centre for Complex Systems in Transition, Stellenbosch University, Matieland, 7602, South Africa \\ d Stockholm Resilience Centre, Stockholm University, Stockholm, SE, 10691, Sweden
}

A R T I C L E IN F O

\section{Keywords:}

Biological invasions

Environmental

management

Global change

Invasive alien species

Novel ecosystems

Resilience

Transformation

\begin{abstract}
A B S T R A C T
There are growing concerns that increasing global environmental pressures could lead to the exceedance of critical ecological thresholds that could trigger long-lasting regime shifts that will affect the structure and function of ecosystems and the broader social-ecological systems in which they are embedded. Biological invasions are a major driver of global change, and a number of invasive species alter key ecological feedbacks in ways that lead to regime shifts, with consequences for biodiversity, ecosystem services, livelihoods and human wellbeing. We present four case studies, chosen to represent a diverse range of ecosystems and invasive taxa, to illustrate invasion-driven regime shifts in a variety of social-ecological systems globally. The case studies are: i) wattle trees (Australian Acacia species) in fynbos shrublands in South Africa; ii) Nile perch (Lates niloticus) in Lake Victoria in East Africa; iii) chestnut blight fungus (Cryphonectria parasitica) within broad-leaved forests of eastern North America; and iv) the floating macrophytes salvinia (Salvinia molesta) and water hyacinth (Eichhornia crassipes) in East Sepik Province of Papua New Guinea. For each case we identify the social and ecological drivers and feedbacks underlying the shift, the impacts on ecosystem services and human wellbeing, and the management options for reducing impacts. We discuss the value of using causal-loop diagrams to improve our understanding of the complex dynamics of shifts, and explore how concepts associated with regime shifts can inform guidelines for enhancing adaptive governance of biological invasions. Identifying species that have the potential to generate high-impact regime shifts, understanding the diversity of consequences for different environments and stakeholders, and developing robust management methods to reduce impacts and restore systems to improve social-ecological resilience and reduce vulnerability are priorities for further research.
\end{abstract}

\section{Introduction}

Biological invasions are a major driver of human-induced global change in the Anthropocene. Some invasive species cause rapid, substantial and long-lasting changes to the structure and function of ecosystems - so-called regime shifts - that are very difficult or impossible to reverse (Scheffer et al., 2001; Gaertner et al., 2014; Hui and Richardson, 2017). Such shifts have major implications for biodiversity and can cause extinctions and large-scale community change (Clavero and García-Berthou, 2005; Hejda et al., 2009; Downey and Richardson, 2016). They can also substantially alter or change the supply of ecosystem services (Pejchar and Mooney, 2009; Le Maitre et al., 2011; Vaz et al., 2017a), and have significant impacts on human wellbeing and livelihoods, through their effect on factors such as human health and agricultural productivity (Shackleton et al., 2007, 2018a). An improved understanding of the conditions under which invasive species may trigger such far-reaching changes to social-ecological systems, the implications of these shifts for ecosystems and people, and options for integrated management of these changes are urgently needed (Millennium Ecosystem Assessment (MA), 2005; Pejchar and Mooney, 2009; Kueffer, 2013; Gaertner et al., 2014). Such advances are crucial for building resilience and adaptive capacity (Folke, 2006; Brooks et al., 2005), in ways that both reduce the likelihood of such shifts (Chaffin et al., 2016) and increase the capacity to deal with unexpected regime shifts if they do occur.

Biological invasions arise due to human-mediated movement of species to new environments and the subsequent interactions of these species with the recipient ecosystems (Hui and Richardson, 2017). Species are introduced both accidently (e.g., in ballast water, or through seeds with imported goods) and intentionally (e.g., as

\footnotetext{
* Corresponding author.

E-mail address: rtshackleton@gmail.com (R.T. Shackleton).
} 


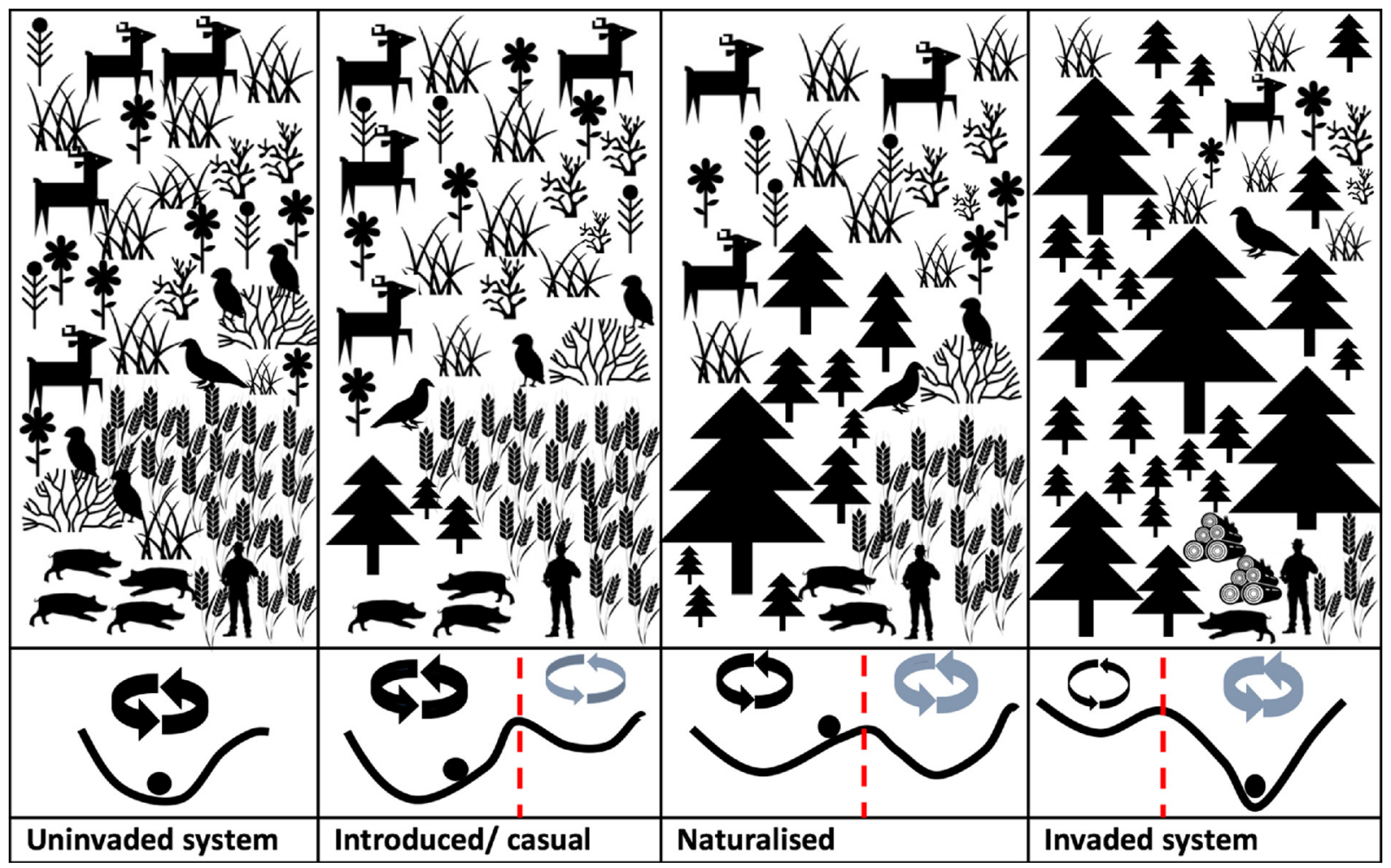

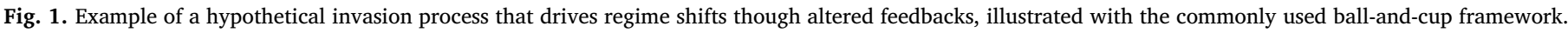

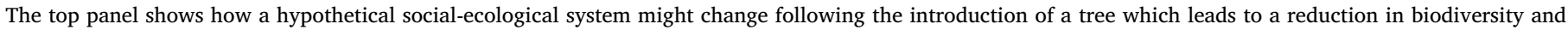

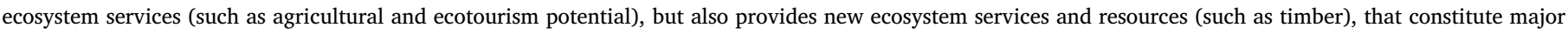

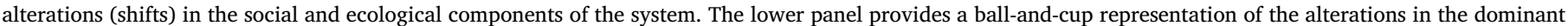

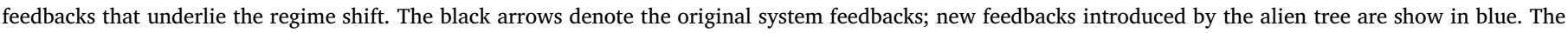

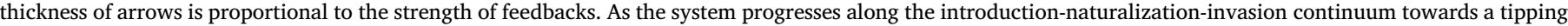

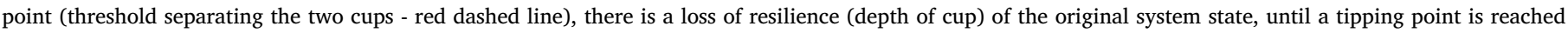

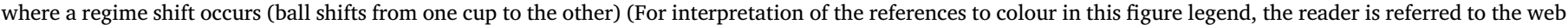
version of this article).

ornamentals and pets, for agriculture and forestry) (Essl et al., 2015a). Introduced species face a number of barriers in their new environment and have to survive, proliferate and naturaly disperse (Blackburn et al., 2011). Those that establish, reproduce and develop self-sustaining localised populations are termed naturalised species. When naturalised species spread from original sites of introduction and increase in abundance and spatial scale they are termed invasive alien species (Richardson et al., 2011) (Fig. 1). Only a small proportion of introduced species become naturalised or invasive, and of those that become invasive, only a small number cause regime shifts. Where they do occur, these shifts are highly scale- and density-dependent and can have farreaching consequences (Gaertner et al., 2014; Hui and Richardson, 2017). Progression along the introduction-naturalization-invasion (INI) continuum can be very rapid, but can also be subject to substantial lags and take several decades or longer (Crooks et al., 1999; Rouget et al., 2016).

Regime shifts are defined as large, persistent (difficult to reverse) changes in the structure and function of social-ecological systems, and are associated with a change in the dominant feedbacks governing system behaviour that lead to a switch between alternative stable states (Scheffer and Carpenter, 2003; Folke et al., 2006; Kinzig et al., 2006; Biggs et al., 2012; Kull et al., 2018). This definition has an ontological basis in resilience/systems thinking, which is the basis of much of our understanding of social-ecological system dynamics (e.g., Adger, 2000; Berks et al., 2003). Regime shifts are usually driven by a combination of external perturbations and slow changes within the system (Andersen et al., 2009; Biggs et al., 2012; Rocha et al., 2015). These perturbations and slow changes can weaken the dominant system feedbacks, reducing the resilience of the current system state, and driving it towards a tipping point. A regime shift occurs once the system reaches a critical threshold (or tipping point/critical transition) where a switch in the dominant feedbacks governing system behaviour significantly alters social-ecological or ecosystem processes and structures (e.g., loss of adaptive capacity, a switch to a new primary livelihood activity and/or a switch in vegetation structure) (Scheffer et al., 2001; Bennett et al., 2005; Kinzig et al., 2006; Biggs et al., 2012; Hammond, 2012; Blythe, 2014; Lade et al., 2013; Kull et al., 2018).

When a species is added to an ecosystem it can act as a primary external perturbation, but it may also interact with other drivers, potentially leading to altered feedback dynamics or to totally novel feedbacks (Biggs et al., 2012; Polasky et al., 2011). Initially, these novel or altered feedbacks are usually weak compared to the dominant feedbacks and energy flows, and the system typically continues to function broadly as before (Fig. 1). However, once an introduced species becomes naturalised, it may start to exert a larger influence on system dynamics. The new or changed feedbacks may become increasingly strong while the system dynamics prior to invasion become weaker and more vulnerable to change and have reduced adaptive and transformation potential (Fig. 1). If the species progresses further along the INI continuum to become a dominant component of the community, it may fundamentally change the ecosystem structure and function and/ or livelihood practices, precipitating a social-ecological regime shift or new stable state (Brooks et al., 2004; Lade et al., 2013; Gaertner et al., 2014; Kull et al., 2018). Many shifts are facilitated by multiple or additional social and ecological shocks (e.g., such as fire, drought or flood), altered land-use practices, or by impacts caused directly or indirectly by other invasive species (Hughes et al., 2013; Kull et al., 2018). 
The dominant feedbacks that underlie and maintain a specific regime are commonly self-reinforcing. Consequently, once a shift from one regime to another has occurred, it is often very difficult, though not always impossible, to reverse (Scheffer et al., 2001; Polasky et al., 2011; Chaffin et al., 2016) - a phenomenon known as hysteresis. It is important to understand the social-ecological dynamics leading up to these shifts and the effects that they cause to aid improved adaptive governance (Brooks et al., 2005).

To date, much of the work on invasion-related regime shifts has focused on ecological mechanisms and effects (Mack and D'Antonio, 1998; Gaertner et al., 2014; Chaffin et al., 2016; Gaertner et al., 2017). There has been a lack of research on the broader social-ecological systems dynamics underlying such shifts, or on the wider consequences of invasion-related regime shifts on ecosystem services and human wellbeing. Only recently, Hui and Richardson (2017) and Kull et al. (2018) considered the dynamics of invasions within the framework of complex adaptive systems, including social-ecological systems and regime shifts. Social-ecological analyses tend to adopt a broader perspective that considers not only the ecological and direct social drivers (e.g., land clearing) of regime shifts, but also indirect social drivers (e.g., changing wealth that affects dietary preferences). Furthermore, the social-ecological perspective considers both the ecological changes or disturbances as well as effects on human wellbeing and livelihoods and other social consequences of regime shifts. With in social-ecological systems, the core feedbacks that underlie the regime shift could be either ecological (e.g., invasive species), social (e.g., shift to a vegetarian diet or new land use pollicies), or comprise interacting social-ecological factors (e.g., common pool resource harvesting, Lade et al., 2013) or the domestication of fire (Biggs et al., 2016). In many cases, a social-ecological perspective can help highlight cascading sets of regime shifts, e.g., the collapse of important fisheries can lead to the reorganization of society as new forms of livelihood need to be adopted. Working on the interface of invasive species and social-ecological systems helps to reinforce a call by Kueffer (2017) for more interdisciplinary understanding in invasion science within the context of the Anthropocene.

In this paper we: examine a set of case studies that shed light on aspects of the underlying social-ecological dynamics of many regime shifts generated by biological invasions; and elucidate how these shifts have influenced biodiversity, ecosystem services, human wellbeing and livelihoods in the broader social-ecological systems in which they are embedded. Using case studies has become a common methodology for providing a deeper understanding and synthesis of the effects of environmental change and for highlighting both complexity and contextspecificity (Ellison et al., 2005; Pejchar and Mooney, 2009; Rocha et al., 2015; Boonstra et al., 2016). We chose four case studies that cover a range of taxonomic groups in different ecosystems (Table 1): i) wattle trees (Australian Acacia species) in fynbos shrublands of South Africa (Shackleton et al., 2017a, 2017b; http://regimeshifts.org/item/611megadiverse-fynbos-shrublands-to-invasive-wattle-tree-monoculture\# ); ii) Nile perch (Lates niloticus) in Lake Victoria, East Africa (Hakansson et al., 2012; http://regimeshifts.org/item/408-lake-victoria\#); iii) chestnut blight fungus (Cryphonectria parasitica) in broadleaved forests of eastern North America (Shackleton et al., 2018a, 2018b http:// regimeshifts.org/item/617-american-chestnut-dominant-forests-to-redmaple-dominant-forests\#); and iv) the floating aquatic plants salvinia (Salvinia molesta) and water hyacinth (Eichhornia crassipes) in East Sepik Province, Papua New Guinea (modified slightly to a new locality but based on the case study by Strange et al., 2017 http://regimeshifts.org/ item/614-invasive-floating-to-submerged-plant-dominance-in-south-

africa\#). The case studies were selected from the Regime Shifts Database (www.regimeshift.org), which has a clearly defined approach and template for synthesizing case studies of social-ecological regime shifts based on the literature and expert knowledge (Biggs et al., 2018). These examples are good model systems (sensu Kueffer et al. (2013b)) in that they have been sufficiently well researched to allow the dynamics, drivers and implications of the regime shifts to be analysed in the

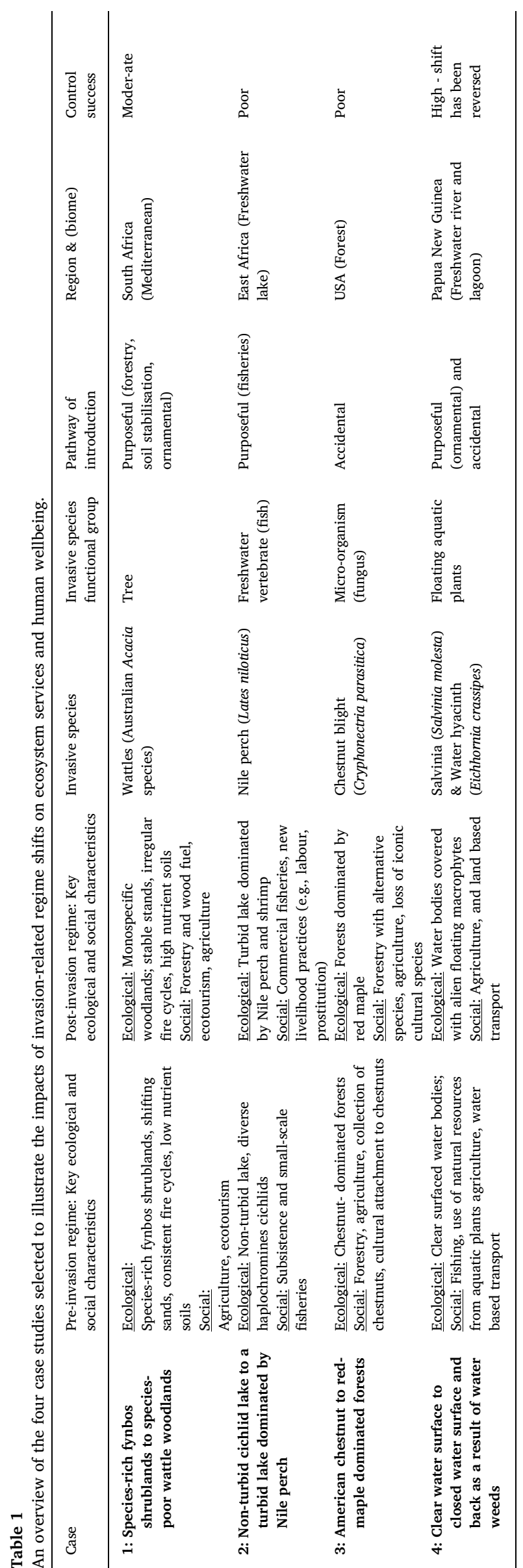




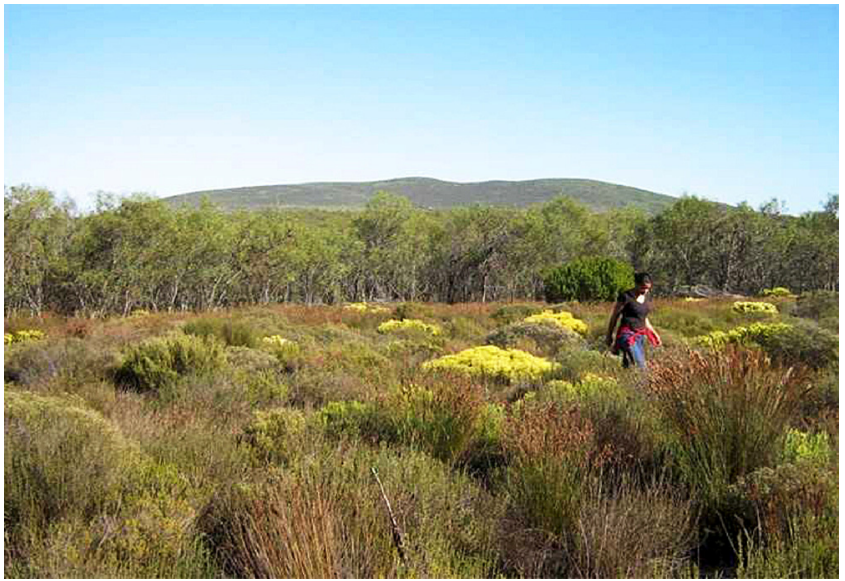

Fig. 2. Contrast between un-invaded/managed fynbos (foreground) and a dense stand of invasive Acacia saligna (background) in Blaauwberg Nature Reserve near Cape Town, South Africa. (Photo source: City of Cape Town).

context of the aims of this paper.

In the following section, we describe each case study, identifying the original and invaded regime, the drivers and feedbacks underlying the shift, the social-ecological effects of the shift (impacts on ecosystem services and human wellbeing), and the management interventions and options that exist for building resilience in the system. The regime shift dynamics for each case study are summarized using a causal loop diagram, as per the regime shifts database template. Based on this analysis, we identify the social-ecological mechanisms that mediate the invasion dynamics, elucidate key impacts of invasive species on ecosystem services and human wellbeing, and consider the implications for invasive species management and governance.

\section{Case study 1: Species-rich fynbos shrubland to species-poor wattle woodlands in South Africa}

The Cape Floristic Region in South Africa is home to the megadiverse fynbos biome (Fig. 2). Fynbos shrublands in this global biodiversity hotspot occur on nutrient-poor soils and experience intense fires at intervals of 5-15 years (Allsopp et al., 2014). The region is important for ecotourism, water production from fynbos-clad catchments, plantbased agriculture and sheep farming.

\subsection{Regime shift dynamics - key drivers and feedbacks}

The introduction of a number of wattle species (Australian taxa in the genus Acacia) for forestry, dune stabilisation and ornamental purposes to fulfil human development and economic needs has led to a patchwork of regime shifts from species-rich fynbos shrublands to species-poor wattledominated woodlands (Figs. 2 and 3). The wattles have altered prevailing feedbacks and led to several new ecological feedbacks that have allowed wattles to become dominant components of vegetation across substantial geographical areas previously dominated by fynbos shrublands. Human disturbance and land use change have also facilitated invasion in many areas, which has been reinforced by human-induced climate change (Fig. 2).

Key changes in feedbacks include changes to soil chemistry, fire regimes, and novel biotic interactions (Richardson and Cowling, 1992; Le Maitre et al., 2011; Gaertner et al., 2014) (Fig. 3). Wattles increase soil organic nitrogen through increased biomass. They are also nitrogen fixers and create novel interactions with soil biota that further modify soil chemistry. Their increased biomass also increases the frequency and intensity of fires, and fires facilitate the mass germination of wattle seeds, thereby reducing reproduction and survival of native species. This shift is facilitated by external drivers such as urbanisation and land-use change (which create disturbed areas that are more susceptible

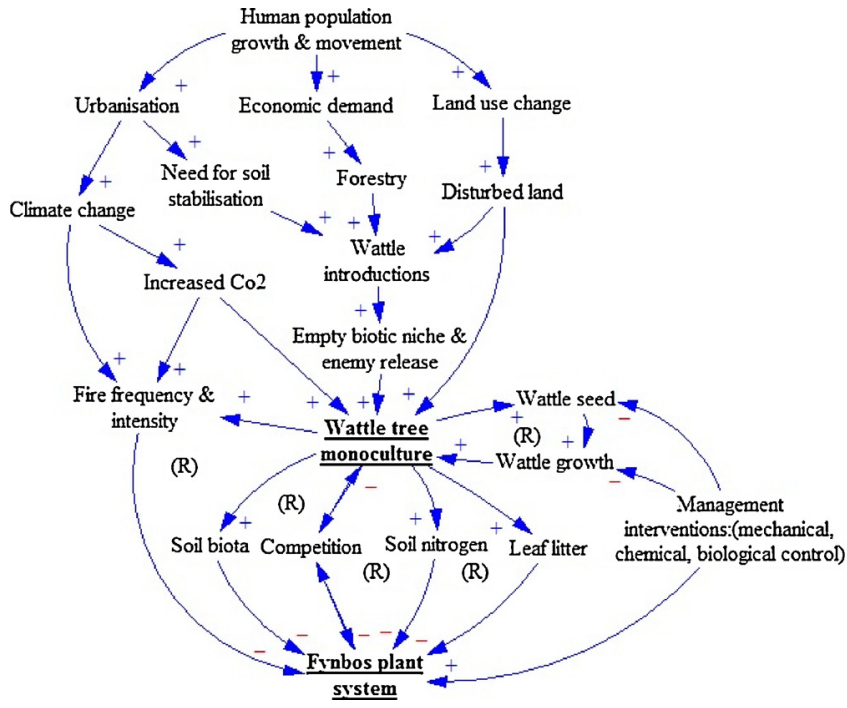

Fig. 3. Causal-loop diagram of the drivers and feedbacks underlying the fynboswattle regime shift. (R) indicates reinforcing feedbacks.

to invasion), climate change (leading to faster growth rates of trees), and economic development (which encourages spread and further planting of the species) (Fig. 3). Fire and disturbance act as flashpoints that facilitate rapid invasions into new areas.

It is difficult to identify when social and ecological thresholds were crossed, as the regime shift has occurred at a regional scale and happened at different times in different places (Gaertner et al., 2012). Based on Gaertner et al. (2014), a working proxy for the threshold is the point at which the biomass of wattles in a given area exceeded that of native fynbos plants. This shift occurred more gradually compared to the other cases discussed in this paper.

\subsection{Implications for social-ecological systems - effects on ecosystem services and human wellbeing}

This shift has resulted in the loss of several important ecosystem services, and thus negative effects on human wellbeing and biodiversity (Tables 2 and 3). In particular, major losses in water supply have occurred, which negatively influences economic productivity, human health and biodiversity in the region (Le Maitre et al., 2011, 2016). Wattles have also reduced rangeland potential and added extra costs for clearing agricultural lands, with substantial economic costs for some stakeholders' livelihoods, increasing their vulnerability and putting pressure on their adaptive capacity (Milton et al., 2003; Leadley et al., 2014). Altered fire regimes associated with the shift pose a threat to human health and safety, and have negatively influenced biodiversity (Gaertner et al., 2014; Souza-Alonso et al., 2017). The invasion has also had negative effects on cultural wellbeing with high impacts on aesthetic value (a sense of place) and ecotourism, especially through the loss of native fynbos vegetation (Pejchar and Mooney, 2009).

On the other hand, wattles also provide tannins, fuelwood, medicinal and cultural value to some stakeholders and some communities have become heavily reliant on this resource. This shift represents a social or cultural shift in resource use and "adoption" of the tree for some communities (de Neergaard et al., 2005; Shackleton et al., 2007; Kull et al., 2011, 2018). As such, the ecological regime shift precipitated by the wattle invasion has also triggered a major social regime shift (sensu Lade et al., 2013; Kull et al., 2018). The fact that wattles supply both benefits and costs creates substantial complexity and conflict between those who benefit from the new regime and those who are rendered more vulnerable (Kull et al., 2011). 
Table 2

A synthesis and comparison of the different ecosystem service impacts of the four case-studies of regime shifts. (+) indicates a positive effect of the shift (supply of benefits); (-) indicates a negative effect (loss of supply(costs); (+/-) represents both a positive and negative change depending on the landscape or stakeholder (supply of both benefits and costs); (?) unclear whether the shift changes the factor (no evidence); (n/a) the shift does not influence that ecosystem service. Evaluation was based on evidence from the literature according to a specalised template designed for producing case studeis for the regime shfit database (regimeshift.org)

\begin{tabular}{|c|c|c|c|c|}
\hline & $\begin{array}{l}\text { Case study 1: Species-rich fynbos } \\
\text { shrublands to species-poor wattle } \\
\text { woodlands }\end{array}$ & $\begin{array}{l}\text { Case study } 2 \text { : Non-turbid cichlid } \\
\text { lake to a turbid lake dominated by } \\
\text { Nile perch }\end{array}$ & $\begin{array}{l}\text { Case study 3: American } \\
\text { chestnut to red-maple } \\
\text { dominated forests }\end{array}$ & $\begin{array}{l}\text { Case study } 4 \text { : Clear water surface to } \\
\text { closed water surface and back as a } \\
\text { result of water weeds }\end{array}$ \\
\hline \multicolumn{5}{|l|}{ Provisioning Services } \\
\hline Freshwater & - & - & $?$ & - \\
\hline Food crops & - & $\mathrm{n} / \mathrm{a}$ & $\mathrm{n} / \mathrm{a}$ & - \\
\hline Feed, fuel and fibre Crops & $+/-$ & $\mathrm{n} / \mathrm{a}$ & - & $+/-$ \\
\hline Livestock & - & $\mathrm{n} / \mathrm{a}$ & - & - \\
\hline Fisheries & $\mathrm{n} / \mathrm{a}$ & $+/-$ & $\mathrm{n} / \mathrm{a}$ & - \\
\hline Wild food \& products & - & - & - & - \\
\hline Timber & + & $\mathrm{n} / \mathrm{a}$ & - & $\mathrm{n} / \mathrm{a}$ \\
\hline Woodfuel & + & $\mathrm{n} / \mathrm{a}$ & - & $\mathrm{n} / \mathrm{a}$ \\
\hline Hydropower & $\mathrm{n} / \mathrm{a}$ & $?$ & $\mathrm{n} / \mathrm{a}$ & \\
\hline \multicolumn{5}{|l|}{ Regulating Services } \\
\hline Air quality regulation & $?$ & $\mathrm{n} / \mathrm{a}$ & $?$ & $?$ \\
\hline Climate regulation & $+/-$ & $\mathrm{n} / \mathrm{a}$ & - & ? \\
\hline Water purification & - & - & - & - \\
\hline Soil erosion regulation & $+/-$ & $\mathrm{n} / \mathrm{a}$ & - & - \\
\hline Pest \& disease regulation & $?$ & - & $?$ & - \\
\hline Pollination & - & $\mathrm{n} / \mathrm{a}$ & $?$ & - \\
\hline $\begin{array}{l}\text { Protection against natural } \\
\text { hazards }\end{array}$ & - & - & $?$ & - \\
\hline \multicolumn{5}{|l|}{ Cultural Services } \\
\hline Recreation & - & $+/-$ & - & - \\
\hline Aesthetic values & - & $\mathrm{n} / \mathrm{a}$ & - & - \\
\hline Cognitive \& educational & - & - & - & - \\
\hline Spiritual \& inspirational & - & - & - & - \\
\hline
\end{tabular}

\subsection{Management options}

Attempts to eradicate several naturalised wattle species are underway to prevent them from becoming invasive (Wilson et al., 2013). The national public works program Working for Water (WfW) is clearing wattle invasions to restore ecosystem services and at the same time provide jobs for poor rural communities (van Wilgen et al., 2012). This project has had mixed success, but has been effective in limiting the spread of wattle and helping with impact reduction and restoration at localised sites. While this has helped to build ecological and socialecological resilience locally (Fig. 1), wide-scale containment and impact reduction is lacking (van Wilgen and Wannenburgh, 2016).

Biological control agents have been released for most of the widespread invasive wattle species and are having a substantial impact on fecundity, thereby limiting spread potential, but the agents have not had a major impact on the distribution and abundance of these species (van Wilgen et al., 2012). Henderson and Wilson (2017) note that wattle species that are under "complete" biological control have shown much smaller increases in range over the period from 2000 to 2016 than those that are not under "complete" control. With time, reduced recruitment and spread of wattles due to effective biological control should translate to reduced impacts and less prominent influence of

Table 3

A synthesis and comparison of the different impacts on human wellbeing of the four case studies of regime shifts. (+) indicates a positive effect as a result of the shift (supply of benefits); (-) negative change effect (loss of supply (costs); (+/-) indicates both a positive and negative change, depending on the landscape or stakeholder (supply of both benefits and costs); (?) unclear whether the shift changes the factor; (n/a) the shift does not influence that ecosystem service.

\begin{tabular}{|c|c|c|c|c|c|}
\hline & \multicolumn{2}{|c|}{$\begin{array}{l}\text { Case study 1: Species-rich } \\
\text { shrubland to species-poor wattle } \\
\text { woodland }\end{array}$} & \multirow[t]{2}{*}{$\begin{array}{l}\text { Case study } 2 \text { : Non-turbid cichlid } \\
\text { lake to a turbid lake dominated by } \\
\text { Nile perch }\end{array}$} & \multirow[t]{2}{*}{$\begin{array}{l}\text { Case study 3: American } \\
\text { chestnut to red-maple } \\
\text { dominated forests }\end{array}$} & \multirow[t]{2}{*}{$\begin{array}{l}\text { Case study } 4 \text { : Clear water surface to } \\
\text { closed water surface and back as a } \\
\text { result of water weeds }\end{array}$} \\
\hline \multicolumn{3}{|l|}{ Safety } & & & \\
\hline Personal safety & - & & $\mathrm{n} / \mathrm{a}$ & $\mathrm{n} / \mathrm{a}$ & $\mathrm{n} / \mathrm{a}$ \\
\hline Secure resource access & - & & - & - & - \\
\hline Security from disasters & - & & - & $?$ & - \\
\hline \multicolumn{6}{|c|}{ Material and immaterial assets } \\
\hline Adequate livelihoods & $+/-$ & & $+/-$ & - & - \\
\hline Sufficient nutritious food & - & & - & - & - \\
\hline Shelter & + & & $\mathrm{n} / \mathrm{a}$ & - & $\mathrm{n} / \mathrm{a}$ \\
\hline Access to goods & $+/-$ & & $+/-$ & - & - \\
\hline \multicolumn{6}{|l|}{ Health } \\
\hline Strength & & $?$ & - & $?$ & $?$ \\
\hline Feeling well & & $?$ & - & $?$ & $?$ \\
\hline \multicolumn{2}{|c|}{ Access to clean air and water } & - & - & - & - \\
\hline \multicolumn{2}{|c|}{ Social, spiritual and cultural relations } & - & - & - & - \\
\hline \multicolumn{2}{|c|}{ Social, spiritual and cultural practice } & - & - & - & - \\
\hline \multicolumn{2}{|c|}{ Mutual respect } & - & - & $?$ & ? \\
\hline \multicolumn{2}{|l|}{ Friendship } & $?$ & $?$ & $?$ & $?$ \\
\hline
\end{tabular}




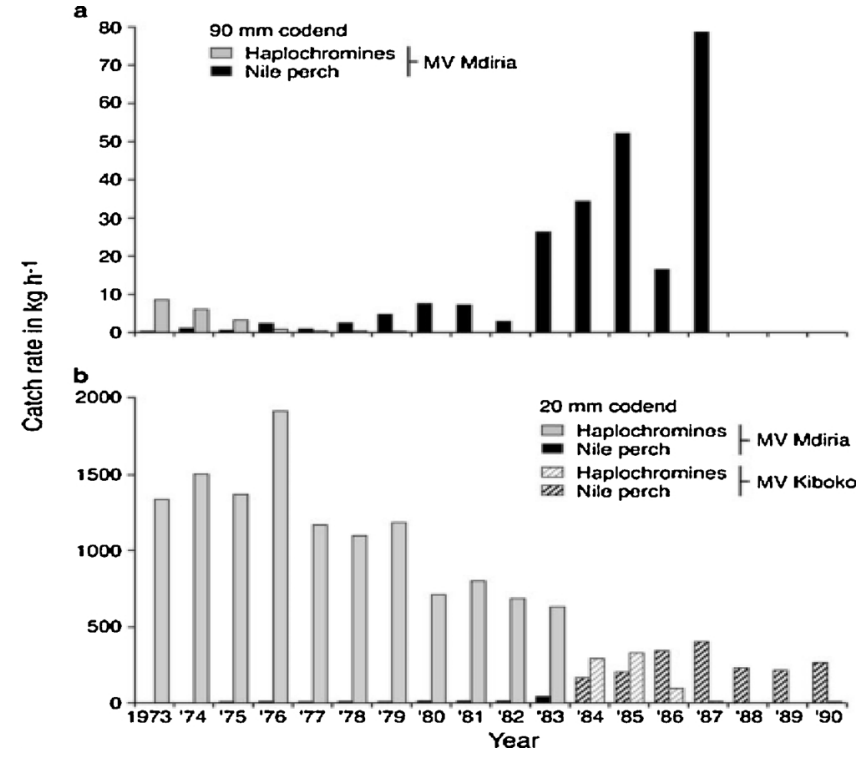

Fig. 4. Cichlid-Nile perch dynamics over time. Showing catch rates of Nile perch and haplochromine fish by bottom trawlers over time with a) $90 \mathrm{~cm}$ nets and b) at $20 \mathrm{~mm}$ nets (Figure sourced form a publication in Environmental Biology of Fishes by Goudswaard et al., 2008).

their reinforcing feedbacks; this could increase the resilience of native ecosystems, and reduce the social-ecological costs of wattle invasions.

3. Case study 2: Non-turbid, diverse cichlid system to a turbid, Nile perch system in Lake Victoria, east Africa

Lake Victoria in East Africa was home to a highly diverse cichlid (haplochromine)-dominated system (Figs. 4). These fish are detritivores and planktivores, and ecologically they helped to maintain nutrient cycling and to prevent eutrophication, hypoxia and turbidity. Prior to the mid-1970s, the cichlid-plankton interaction was the primary feedback within the system (Seehausen et al., 1997). Cichlids were also important for gender-equal subsistence fisheries that sustained the livelihoods of villages around the lake (Abila and Jansen, 1997; Goudswaard et al., 2008).

\subsection{Regime shift dynamics - key drivers and feedbacks}

Nile perch (Lates niloticus) was introduced in the 1950s to increase the value of commercial fisheries in Lake Victoria and to stimulate economic development (a social driver behind the intorcution of the fish). This highly aggressive predator introduced a new ecological feedback (predation of cichlids) to the system, and depleted cichlid populations in the lake (Fig. 4) (Goudswaard et al., 2008; Downing et al., 2014). This predation altered the original cichlid-phytoplankton feedback, thereby increasing phytoplankton and nutrient levels within the lake (Fig. 5). The resultant eutrophication and algal blooms (Fig. 5) further altered and reinforced water chemistry changes, leading to hypoxia (Seehausen et al., 1997; Balirwa et al., 2003). Poor land-use practices have also resulted in nutrient inputs that reinforced this shift and is effects (Fig. 5) (Witte et al., 2012). An ecological threshold or tipping point was reached for larger cichlids in 1976 and for smaller fish in 1983 (Fig. 4). Models suggest that board-scale tipping points could have been predicted based simply on exponential growth models of Nile perch, with other social and environmental factors paying minor roles. At more localised scales the Allee effect and small differences in habitat might have slightly altered tipping points and invasion success in different locations of the lake (Downing et al., 2013). The precise social tipping point of loss of livelihoods and changes in behaviour associated with increased vulnerability (Lade et al., 2013; Blythe, 2014;

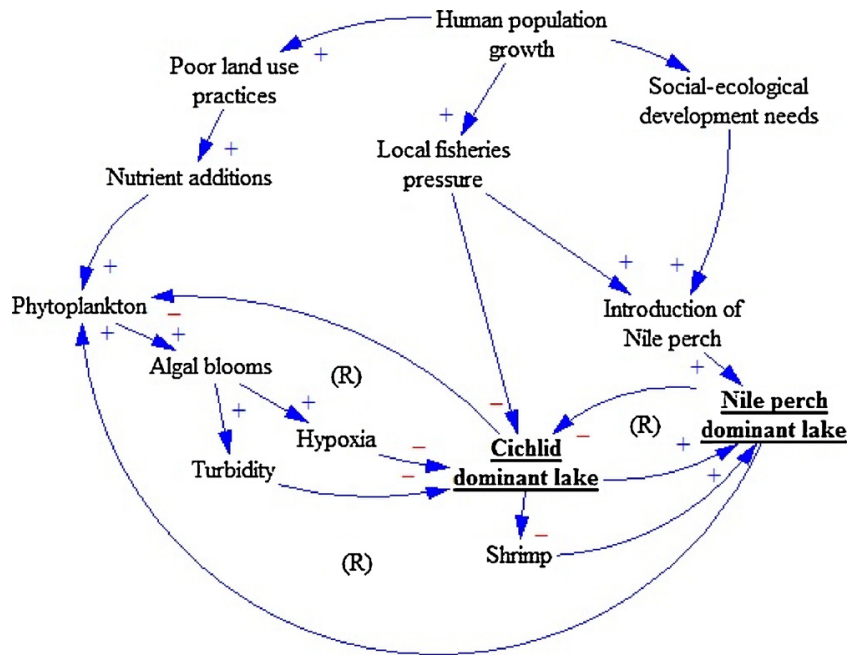

Fig. 5. Causal-loop diagram of the drivers and feedbacks underlying the cichlidNile perch regime shift. (R) indicates reinforcing feedbacks.

Leadley et al., 2014) is difficult to identify, but would have lagged slightly behind the ecological threshold.

\subsection{Implications for social-ecological systems - effects on ecosystem services and human wellbeing}

This shift has resulted in oxygen depletion, increased eutrophication and increased turbidity, causing negative effects on ecosystem structure and function (Seehausen et al., 1997) (Tables 2 and 3). This has negatively altered water chemistry, leading to health-related issues for local communities and negative impacts on biodiversity. The shift has also resulted in the increased presence of native freshwater shrimp, triggering a substantial ecological change in the system. Loss in the supply of the fish (provisioning services) that sustained small-scale subsistence fisheries has led to the loss of livelihoods for many communities around the lake (Appleton, 2000). Industrial-scale fishing and export of Nile perch, and to a lesser extent commercial sport fishing by recreational anglers and local guides, has benefited powerful actors and corporate entities at the expense of many poor and marginalised substance fishing community members (Johnson, 2010). Women from marginalised communities in particular have been disadvantaged, and have had to adopt new livelihood practices, prostitution being a primary one, because of the reduction in subsistence fishing (Appleton, 2000; Molony et al., 2007). This has in turn spurred inequality, social conflict, health issues, the loss of cultural practices, and reduced food security for local communities, thus affecting human wellbeing (Appleton, 2000; Molony et al., 2007) (Table 3). It has also led to a change in behaviour and livelihood practices that has had substantial implications for livelihood vulnerability, adaptive capacity and transformative ability, and suggests a substantial social regime shift in the area (Lade et al., 2013; Blythe, 2014; Leadley et al., 2014; Kull et al., 2018).

\subsection{Management options}

No management is currently underway to reverse this shift and/or to restore the native ecosystem, or to reduce the social and ecological vulnerabilities introduced by the shift. The prospects for the eradication of Nile perch are extremely remote and many cichlid species are already extinct, which means that restoring the system to its original state is a futile aim. It has been suggested that the focus of restoration should rather be on community development and land-based ecological restoration to mitigate against the negative social-ecological impacts of the shift (Balirwa et al., 2003). A number of groups are actively trying to manage the social implications of the shift to improve human livelihoods and wellbeing and to reduce vulnerability and promote 


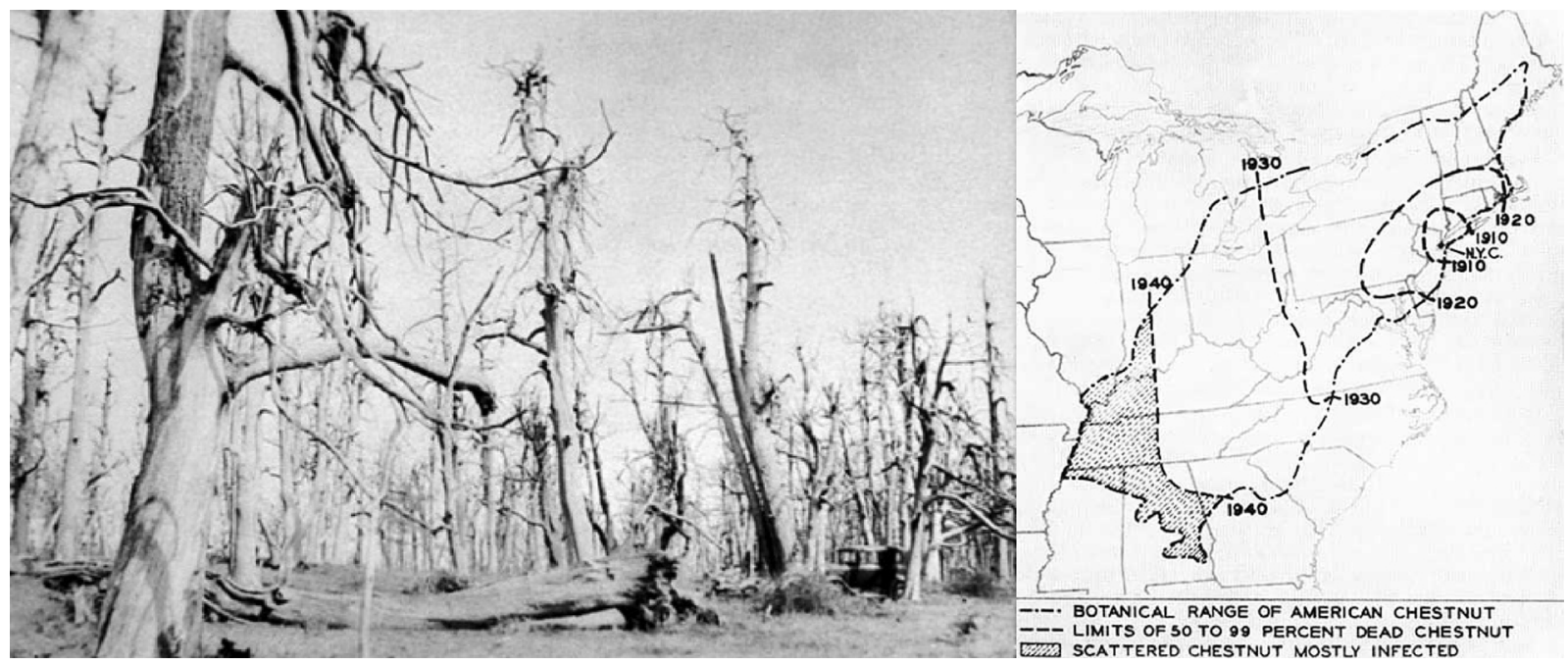

Fig. 6. a) American chestnut trees killed by chestnut blight and b) a map of blight spread in eastern North America (source: US government, Library of Congress HAER VA,70-LURA.V,4-97; map from Gravatt, 1949 and also used in Anagnostakis, 1987).

transformation and adaptive capacity, especially amongst women who lost their livelihoods (Swallow, 2009; LVFO, 2011). It has also been proposed that increasing the fishing intensity of Nile perch, along with preventing sources of eutrophication through better sewage treatment and land practices, could eventually lead to the return of some cichlid species that persist in low densities. This could improve small-scale local fisheries that could complement the commercial Nile perch fisheries (Balirwa et al., 2003).

\section{Case study 3: American chestnut dominated forests to maple tree dominated forest in eastern North America}

In the 19th century, the forests of eastern North America were dominated by American chestnut trees (Castanea dentata) (Fig. 6). Chestnuts formed $40-85 \%$ of the canopy cover of these forests and were a keystone species, particularly in their role as a source of food and shelter for animals (McCormick and Platt, 1980). Chestnuts were also highly prized by humans for timber, tannin, food and fodder, and had a strong cultural significance for many communities (Anagnostakis, 1987; Freinkel, 2007).

\subsection{Regime shift dynamics - key drivers and feedbacks}

The invasive chestnut blight fungus (Cryphonectria parasitica) was accidently introduced into the USA from Asia in the early 1900s through increased economic trade between the two regions. Between 1910 and the 1940-50s the invasive fungus killed 99\% of all American chestnut trees over an area of 3.6 million ha (Anagnostakis, 1987) (Fig. 6), leading to a regime shift in the system. For up to 50 years following the death of chestnuts, many forests in the region had large gaps. In time, hickory and other trees filled these gaps through natural succession to become the dominant forest species over large parts of the central-eastern USA (McCormick and Platt, 1980).

The social key drivers behind this regime shift was the proliferation of global trade in goods, leading to the accidental introduction of the fungus, and later policies that restricted fires in the USA (McCormick and Platt, 1980) (Fig. 7). Key feedbacks included novel interactions between the fungus and chestnut trees that were linked to lack of biotic resistance of the new disease, competition between species, and fire (Fig. 7). The ecological threshold (dominance of American chestnuts to no American chestnut trees) was associated with a rapid and radical ecosystem-level change over 40 years where chestnut abundance dropped form $40-85 \%$ of canopy cover to less than $1 \%$.

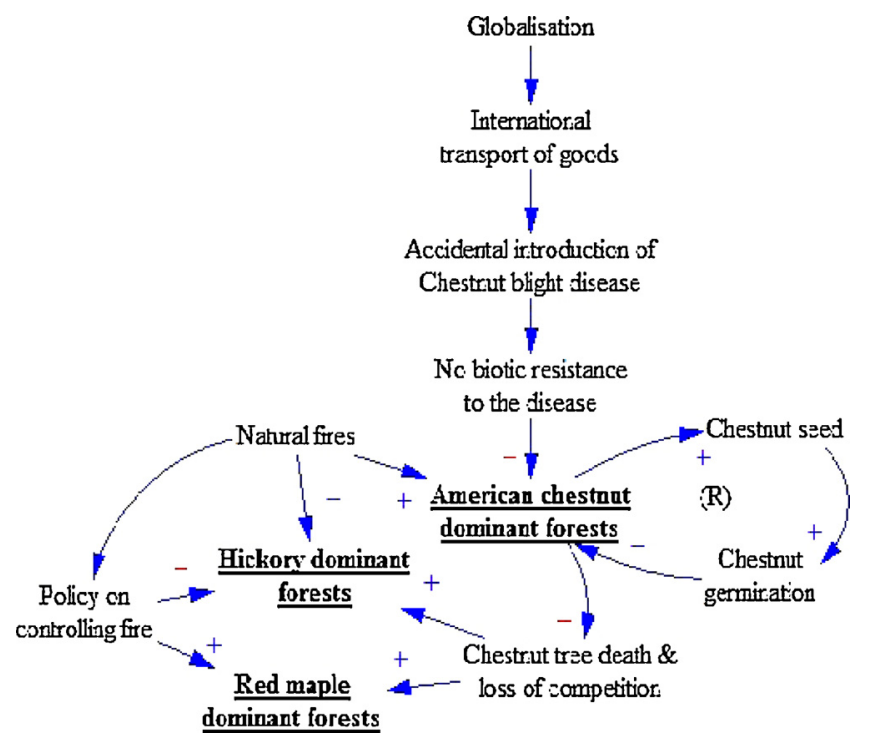

Fig. 7. Causal-loop diagram of the drivers and feedbacks underlying the regime shift caused by chestnut blight. (R) indicates reinforcing feedbacks.

\subsection{Implications for social-ecological systems - effects on ecosystem services and human wellbeing}

The loss of American chestnuts had major negative impacts on ecosystem services and human wellbeing (Tables 2 and 3). These included the alteration of nutrient cycles, which affected water, soil quality and biodiversity (Smock and MacGregor, 1988; Ellinson et al., 2005; Rhoades, 2006). It also resulted in the loss of provisioning services including timber, fodder, tannin and food supply (nuts) to local communities (Anagnostakis, 1982). The regime shift therefore increased the vulnerability of local communities dependent on these resources. In particular, losses to the timber industry had substantial economic impacts. Nuts were also collected by poor families and traded or bartered for other goods and services; the loss of this resource had implications for their livelihood security and increased their vulnerability. This meant that new industrial and livelihood practices or substitutes needed to be found. It also resulted in the loss of an iconic species in the area, thus negatively affecting cultural wellbeing (Freinkel, 2007). The evidence for breached ecological thresholds is clear, as are the obvious negative effects for society. However, it is less 
clear whether thresholds that represent social shifts were exceeded, depending in part on the definition being used (Lade et al., 2013; Leadley et al., 2014; Blythe, 2014).

\subsection{Management}

Attempts to prevent the spread and impacts of the fungus have been made in the past (early to mid-1900s). These attempts included the use of chemicals and biological control (through the release of transmissible hypovirulent forms of the fungus), both of which failed in the USA (Anagnostakis, 1982; Milgroom and Cortesi, 2004). Biological control in Europe was more successful because it involved a different species of chestnut that had evolved transmissible hypovirulence (a form of biological control where a virus is used to control a fungus) (Anagnostakis, 1987; Heiniger and Rigling, 1994; Milgroom and Cortesi, 2004). This prevented a similar shift from taking place in Europe, where chestnuts are still a common and economicaly important tree (Heiniger and Rigling, 1994). Attempts are now being made to breed and genetically modify blight-resistant strains of American chestnut trees to replant into the forests of eastern North America (Diskin et al., 2006; Jacobs, 2007).

5. Case study 4: Open-surface water sources to closed surfaces and back; the case of an effectively managed shift involving the invasive floating macrophytes salvinia (Salvinia molesta) and water hyacinth (Eichhornia crassipes) in the East Sepik Province, Papua New Guinea

The East Sepiak Province has a number of large lakes and is home to one of Papua New Guinea's largest rivers - the Sepik. The regime prior to invasion included freshwater rivers, lakes and lagoons with open surfaces. The system was regulated by water flow rates, sun penetration, and biotic interactions. The Sepik was important for sustaining local livelihoods though water provision, transport, fishing and the provision of other natural resources.

\subsection{Regime shift dynamics - key drivers and feedbacks}

Two invasive floating macrophytes, salvinia and water hyacinth, now completely cover many of the freshwater bodies in East Sepiak. Salvinia (Salvinia molesta) was introduced to Papua New Guinea in the 1970s. Within a decade it had covered the surface of more than 500 $\mathrm{km}^{2}$ of freshwater lakes and rivers in East Sepiak (Mitchell et al., 1980). Water hyacinth (Eichhornia crassipes) was introduced initially for ornamental purposes into Asia and Oceania, but was likely accidently introduced into Papua New Guinea and had covered the surface of water bodies in East Sepiak by the 1980s (Julien and Orapa, 1999) (Fig. 8). The key drivers behind this shift included the introduction (likely accidental) of the floating macrophytes due to globalisation,

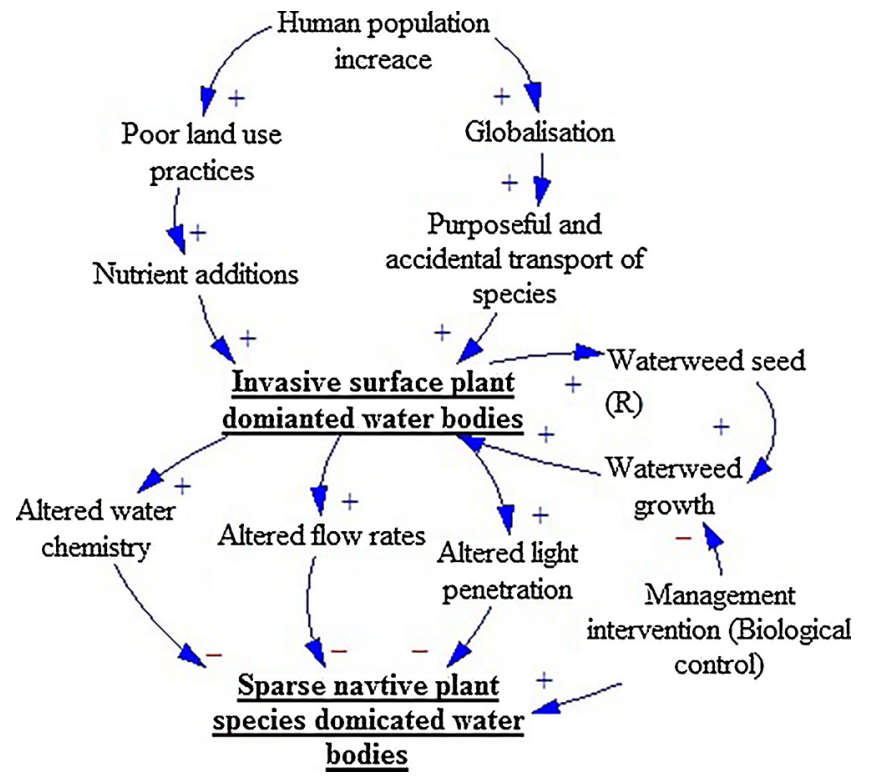

Fig. 9. Causal-loop diagram of the drivers and feedbacks underlying the regime shift caused by invasion of Eichhornia crassipes and Salvinia molesta. (R) indicates reinforcing feedbacks.

population increase and movement, and poor land-use practices that increased water nutrients and helped the invasive plants to establish (Fig. 9). Key feedbacks included alterations to water chemistry and nutrients, flow rates and light penetration as a result of the biological invasion, which were coupled with and reinforced by poor land use practices (Fig. 9). This shift lasted for around two decades. However, through effective management, particularly using biological control (see below), the system has reverted to its original open-surface water regime.

\subsection{Implications for social-ecological systems - effects on ecosystem services and human wellbeing}

The coverage of water surfaces by these two floating macrophytes had huge negative implications for people and the environment, and almost no benefits (Tables 2 and 3). They altered flow rates, which increased flooding and reduced water quality (Mitchell et al. 1980). The invasions also altered water chemistry, which had negative health effects for humans and biodiversity. These two floating macrophytes reduced fish populations which had negative implications for food security and local livelihoods, substantially increasing vulnerability of local communities. The invasions also hindered the harvesting of the non-timber forest product, Sago palm, which is a staple food source in

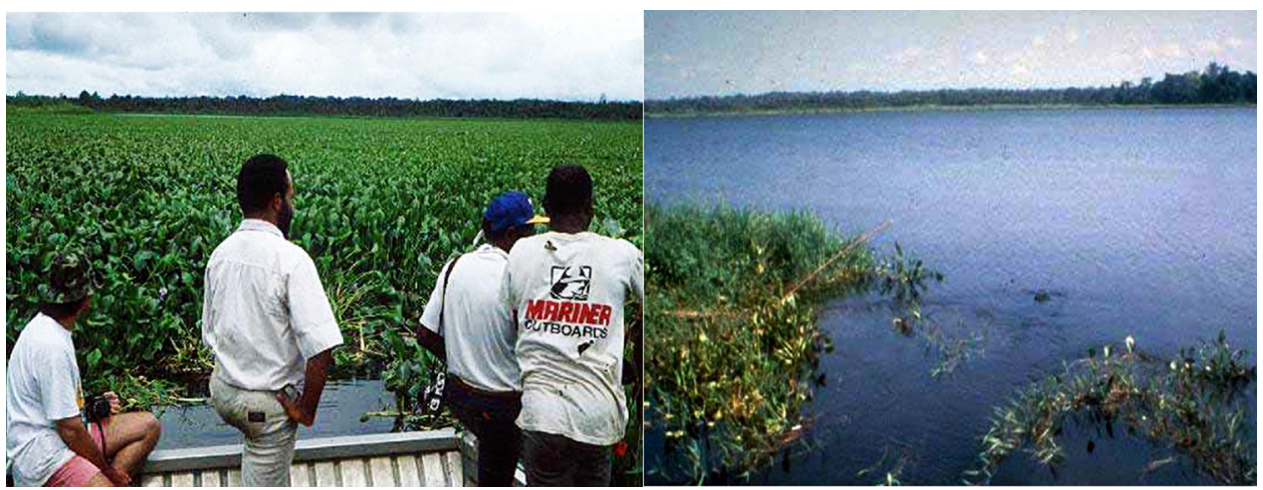

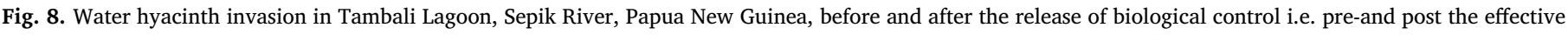
management of the regime shift (Photos: CSIRO). 
the area, causing negative effects on food security and local economic production (Mitchell et al., 1980). Water is a key mode of transport in the area, and the dense cover of the invasive floating macrophytes hindered people's movement (Thomas and Room, 1985). This invasion has been blamed for impacting transport to schools and hospitals, thus affecting education and health care. The two invasive species also damaged pumping infrastructure and provided breeding sites for a number of disease vectors (e.g., mosquitoes and snails, Julien et al., 2001). They also reduced cultural services, including both aesthetic value and recreation since boating, fishing and swimming became difficult. They were also a key driver of biodiversity loss in aquatic systems, resulting in economic and cultural losses. All of this led to an ecological shift as defined by Gaertner et al. (2014) and might constitute social regime shifts as discussed by Leadley et al. (2014).

\subsection{Management options}

The shift from open water bodies to water bodies covered by salvinia and water hyacinth lasted around two decades but has been successfully managed (Julien et al., 2007). Mechanical clearing was initially attempted but was not successful. Several biological control agents were later released that were successful in reversing the shift (Julien and Orapa, 1999). Cyrtobagous salviniae was released in 1982 and established well, causing dieback of salvinia by 1985 (Thomas and Room, 1985). For water hyacinth, a number of agents were released, including Neochetina bruchi, Neochetina eichhoriniae (weevils), Niphograpta albigutallis and Xubida infusellus (moths) between 1986 and 1996 and control was achieved by 1991 (Julien et al., 2007). International collaboration in implementing a well-structured biological control program was a key ingredient in the success (Julien and Orapa, 1999).

\section{Discussion}

The four cases in this paper demonstrate that invasion-driven regime shifts are highly complex and can have profound consequences for social-ecological systems. The social, ecological and interacting socialecological mechanisms and feedbacks underlying these shifts differ widely, which affects the options for preventing invasion-related regime shifts or restoring invaded ecosystems. There are also issues relating to differences in spatial and temporal scales of trade-offs between the benefits and costs of these regime shifts, which are further complicated by differences in power dynamics, vulnerability contexts, and adaptive capacity amongst different stakeholders (Chapin et al., 2010; Kull et al., 2018). Consequently, response strategies and adaptation options are variable and context specific, leading to complexities for governance of what are in many cases "wicked problems" (Woodford et al., 2016). Although this is a first step, better knowledge of the socialecological dynamics and effects of regime shifts arising from invasive alien species can help justify and aid the implementation of effective management strategies to improve resilience and adaptive governance (Chaffin et al., 2016). This can help to limit negative effects on people and the environment, thereby reducing overall vulnerability to this important driver of global change.

\subsection{How common are regime shifts due to of invasive alien species?}

Using a meta-analysis, Gaertner et al. (2014) found that out of thousands of invasive plant species globally, only 173 are known to have traits that could affect ecosystem structure and functions enough to cause ecological regime shifts. Similarly, Zengeya et al. (2017) show that of all the species formally listed as invasive in South Africa (552), more than half $(55 \%)$ have little or low overall benefits or costs for humans or the environment and can be considered as fairly inconsequential. These assessments and many others suggest that only a small proportion of invasive species have major impacts (Blackburn et al., 2014); therefore, only a small proportion of invasive alien species are likely to cause regime shifts. Where they do occur regime shifts can, however, have major implications for society and the environment. It is therefore important to gain a better understanding of the mechanisms and effects of species that have the potential to cause regime shifts.

The four cases we have discussed are broadly representative of invasive species that generate regime shifts. For example, other species of wattles have had similar impacts to those discussed in Case study 1 in other parts of the world (Kull et al., 2011; Souza-Alonso et al., 2017; Kull et al., 2018), and Prosopis species have changed arid grasslands and shrublands to woodlands in several regions globally (Shackleton et al., 2014). The invasive shrubs Chromolaena odorata and Lantana camara have changed open-understory forests, agro-forests and savannas to closed forests and savannas, and modified fire regimes and soil properties, thereby affecting livelihoods through losses in agricultural production and the ability to collect natural resources (Sharma et al., 2005; Bhagwat et al., 2012; Day et al., 2013; Kannan et al., 2014; Shackleton et al., 2017a). Many invasive grass species modify grasslands and savannas through alterations to fire feedbacks and productivity (Brooks et al., 2004; Gaertner et al., 2017; Linder et al., 2018) and can have severe impacts on rangelands and associated livelihoods (Godfree et al., 2017).

There are also examples of animal species causing regime shifts. North American beavers (Castor canadensis) in Chile have changed hydrological systems from fast moving to slow moving by cutting down trees to build dams, which has altered nutrient cycling and transformed forest banks to grasslands (Anderson et al., 2006), with negative impacts for local agricultural communities and increased human vulnerability though flooding. American red swam crayfish (Porcambarus clarkia) have led to regime shifts by changing many shallow macrophyte-dominated clear-water European lakes into phytoplanktondominated turbid systems (Shin-ichiro et al., 2009; Chaffin et al., 2016). Invasive lionfish (Pterois volitans) have changed diverse mesophotic coral reefs to low-diversity algal-dominated systems (Lesser and Slattery, 2011), with effects on nutrient cycling and water quality. Predation by lionfish on other reef fish has negative effects for subsistence fishing, thereby impacting cultural services and economic profitability of diving-related tourism (del Carmen Carrillo-Flota and Aguilar-Perera, 2017). The lionfish case is similar to the Nile perch case study except that it occurs in a marine environment and that the primary pathway of introduction for the invader was accidental instead of purposeful.

Other invertebrates and microorganisms have also driven shifts. The invasive hemlock woolly adelgid (Adelges tsugae) is destroying hemlock (Tsuga canadensis) forests in North America, with impacts on water, soil and climate regulation services, cultural services and identity, and important animal habitat (Ellinson et al., 2005). The invasive alien silverleaf whitefly (Bemisia tabaci) consumes crops and carries disease; in Uganda it facilitated the spread of the cassava mosaic disease virus which decimated crops for a number of years leading to the migration of people and thousands of deaths, resulting in an agricultural shift in the production staple foods in the country (Legg and Thresh, 2000). There are many more cases of invasive-driven social-ecological regime shifts, with different underlying causes and effects, which emphasizes the need for further research in this area.

\subsection{Multiple, complex causal dynamics underlie social-ecological regimes} shifts

Our four case studies reveal significant complexity in the form of multiple, interacting causal factors and pathways surrounding regime shifts driven by invasive alien species (Woodford et al., 2016). In many cases, invasive species are a key catalyst for the shift, but they frequently interact in with other factors which are typically not considered in invasion biology research, which in many cases focuses on ecological aspects and ignores or gives scant attention to other factors (Vaz et al., 2017b). Furthermore, the diverse array of invasive taxa, whose impacts 
vary depending on the particular social-ecological setting, and the range of different pathways of introduction and spread, influence the impacts (benefits and costs) relating to the shift (Table 2). We used causal loop diagrams to unpack the social and ecological dynamics associated with the introduction of invasive species that ultimately led to regime shifts in the four case studies (Figs. 3,5,7 and 9). This systemsanalysis tool highlights interactions between social and ecological factors and helps to identify and understand the key drivers and feedbacks underlying the shift, and the consequences of these shifts. We found this approach very useful for unpacking this complexity. For example, it helped us to better understand the interplay of different drivers which are sometimes separated by significant time lags. The regime shift triggered by chestnut blight had only one primary driver (increase in global trade leading to an accidental introduction of the fungus), but years after the original shift, alterations to fire policy (a second driver) caused further changes in forest composition in some areas (Fig. 7). The Nile perch case study had a large number of drivers, including human population increase, land degradation, livelihood and economic development needs, similar to the wattle case study (Fig. 5). The four case studies also revealed diverse feedbacks underlying the regime shifts (Figs. 3,5 and 7). For example, there were a number of primary feedbacks in the wattle case study relating to soil change, biotic interactions, competition and fire. There were fewer primary feedbacks in the chestnut blight case study (biotic interactions), but a significant secondary driver (human-induced changes to the fire regime) was implicated. The shifts also operated on different time scales - the chestnut blight shift was extremely rapid, compared to the wattle case study where it took decades for the trees to spread and become dominant over large areas. This highlights the importance of time lags that delay the manifestation of regime shifts (Essl et al., 2015b; Rouget et al., 2016). We also found that species that were introduced intentionally were associated with a range of livelihoods and economic benefits (e.g., wattles for forestry, soil stabilisation, and fuelwood; and Nile perch for food production and economic development), whereas species introduced for cultural (ornamental) reasons (e.g., water hyacinth) and accidentally (e.g., chestnut blight) (Table 1) had fewer or no benefits.

Although we did not examine this point specifically, there is evidence that some ecosystems (such as forests) may be more resilient to regime shifts caused by invasive alien plants, whereas others (such as shrublands in Mediterranean-climate zones, freshwater systems and human-disturbed areas) are more vulnerable to large-scale invasions and regime shifts, due to particular interactions between species traits and ecosystem features (Richardson et al., 1996; Chytrý et al., 2008; Iannone et al., 2016). Similarly, some areas may also be hotspots for introduction and invasion as well as being more susceptible to regime shifts, due to key introduction pathways, (e.g., coastal areas with large harbours; Drake and Lodge, 2004; Hulme, 2009). In contrast, some areas might have higher resilience to invasions and their effects due to specific institutions and governance structures, which influence livelihood practices, management capacity, response times, social memories, adaptive capacity and more (Walker et al., 2004). For example, through effective policy and governance relating to biosecurity, Australia and New Zealand have a reduced likelihood of new, potentially high-impact invasive species being introduced compared to other regions of the world (Keller et al., 2007). Substantially more work is needed to determine what combinations of social and ecological characteristics make different social-ecological systems more susceptible to regime shifts, and how to reduce the vulnerability of these systems.

More research is needed to identify tipping points, feedbacks and impacts to better understand and identify when invasive species have the potential to trigger regime shifts. The criteria proposed by Essl et al. (2017) for assessing the impacts of invasive species are useful in this regard. Improved understanding could help both to prevent and also to restore shifts driven by invasive alien species. A more comprehensive understanding of the range of dynamics associated with regime shifts based on model case studies (e.g., the ones reviewed here for which causal loops have already been developed) can help to improve our understanding and possibly to detect 'early warning signals' for pending regime shifts, which may help in prioritising management interventions (Hui and Richardson, 2017). Phenomena such as 'critical slowing down' assessed through analysis of eigenvalues, and increased variance and autocorrelation in a systems state, are generic dynamics associated with the loss of resilience as a tipping point is approached, and can be used as an early-warning signals for pending shifts (Scheffer et al., 2009). These methods need to be developed and tested based on well-known case studies, and then potentially applied to other species for use as early-warning systems.

\subsection{Impacts of invasion-related regime shifts on ecosystem services and human wellbeing and complexity around benefits and costs}

In many cases, social-ecological regime shifts induced by invasive alien species can have severe negative impacts. However, in some cases they have both positive and negative effects for ecosystem services, livelihoods and human wellbeing, depending on the stakeholder groups and their power dynamics and/or landscape and land-use contexts (Tables 2 and 3) (Shackleton et al., 2007; Jeschke et al., 2014; Potgieter et al., 2017; Vaz et al., 2017a). The supply of benefits and or costs is determined by a number of factors, including i) species traits; ii) reasons for introduction; iii) changes over time in contributions of the invasive species to ecosystem services and disservices; iv) ecosystem type; v) land-use tenure; vii) human vulnerability context; viii) the supply of novel products or availability of substitutes; and ix) time scales and invasion density (Shackleton et al., 2007; Kull et al., 2011). In the wattle and Nile perch case studies, where the species were purposefully introduced for economic reasons, both benefits and costs were experienced as a result of the shift, leading to complexity and conflicts of interest surrounding policy and management of the perch (Novoa et al., 2018). In contrast, the case studies involving accidental introductions (chestnut blight fungus and water weeds) had no benefits but major costs, although this probably does not hold for all accidental introductions. Nevertheless, based on our case studies, species that provided a resource such as fish and wood, seem more likely to have both benefits and costs for ecosystem services and human wellbeing. Also, in our four case studies, benefits in terms of regulating and cultural services associated with regime shifts seem to be less than for provisioning services (Tables 2 and 3), although the situation may be different in other cases where, for instance, cultural benefits might be substantial (Kueffer and Kull, 2017). For example, invasive beavers in South America that have caused an ecological regime shift but provide cultural benefits relating to intrinsic human values associated with this charismatic species (Schüttler et al., 2011). A more thorough metaanalysis, considering the positive and negative effects of regime shifts driven by of invasive species for ecosystem services and human wellbeing, is needed to better assess overall costs and benefits of invasiondriven regime shifts.

Benefits and costs resulting from regime shifts are also dependent on the stakeholder groups affected. Benefits are often acquired by some groups at the expense of costs incurred by other groups. In the case of wattles, commercial foresters and subsistence fuelwood collectors gain at the expense of other groups such as those involved in ecotourism, urban residense who relay in water form rural catchments, or farmers wanting to graze livestock or plough fields (Tables 2 and 3). Some groups (e.g. women) are also more susceptible to negative impacts of regime shifts, such as reductions in personal safety associated with dense wattle invasions in South Africa (see case study; Shackleton et al., 2007). Similarly, in the Nile perch case study, some stakeholders gained substantial income through commercial fishing and processing of Nile perch, at the expense of poor subsistence fishers - especially women (see case study 1; Tables 2 and 3). This loss of livelihood has resulted in the need to find alternative strategies, which has given rise to prostitution and a rise in associated diseases such as HIV, as well as issues of safety 
(Table 3). Therefore, there has been an increase in vulnerability and loss of adaptive and transformative capacity and a change in livelihoods actions and behaviours (Lade et al., 2013; Leadley et al., 2014). The opposite is true for wattles, where many communities have created new livelihood strategies based on the novel ecosystems created by the wattle trees (Shackleton et al., 2007; Kull et al., 2011). These different effects as a result of these regime shifts can lead to complex conflicts of interest which can greatly complicate management. In yet other cases, species such as chestnut blight negatively affected everyone and provided no benefits. However, some groups were affected more directly (e.g., those involved in timber production or collecting nuts to barter), compared to others (e.g., farmers who might have suffered more of a cultural loss rather that economic one) (Appleton, 2000). Understanding and categorising the diverse social consequences of regime shifts, and when they add up to constituting social shifts in their own right, would benefit from more investigation (Blythe, 2014).

\subsection{Preventing and managing social-ecological regime shifts as a result of invasive alien species}

There is a need to manage invasive alien species to prevent them from inducing regime shifts, to mitigate the extent of or adapt to the negative effects once a shift has happened, and in some cases to try to reverse the shift. All these facets require adaptive management and governance responses (Biggs et al., 2009; Armitage et al., 2009; Foxcroft and McGeoch, 2011; Crépin et al., 2012; Chaffin et al., 2016). Here we briefly give an overview of management practices and discuss policy recommendations for each of these three scenarios.

\subsubsection{Prevention (preventing or stopping regime shifts from taking place)}

The most cost-effective mechanism for managing invasion-driven shifts is to prevent invasive alien species from arriving and establishing in the first place. However, strategies to achieve this still lag behind post-introduction reactionary governance (Keller et al., 2007). A number of countries have effective biosecurity programs (risk assessments, boarder checks, sterilisation, etc.) in place that aim to prevent the introduction of high-risk alien species (Meyerson and Reaser, 2002; Keller et al., 2007), but most countries lack the resources and expertise to implement such programs (Early et al., 2016). Preventative measures are particularly important in light of findings from Seebens et al. (2017) which show that the introduction of alien species is still on an upward trajectory globally.

However, not all invasive species can be prevented from entering a country, and may have already been introduced and be in a lag phase (Crooks et al., 1999). Once a species has entered a region, it is most cost effective to eradicate or contain it before it begins to spread during the casual or naturalisation phases (Fig. 1), which is a management approach often termed early detection and rapid response (EDRR) (Wilson et al., 2011). The financial and capacity resources needed for management are much lower than trying to manage widespread species once it has triggered a regime shift.

Overall, improving prevention of potential regime shifts caused by invasive alien species needs more research and improvements in policy and governance. Priorities include: 1) building better policies, governance institutions and capacity to improving biosecurity measures in many parts of the world where they are not implemented; 2) promoting awareness and international cooperation regarding biosecurity - similar to and building on the ballast water convention; 3) building assessment of the likelihood of a given species ability to drive a regime shift into widely applied risk-assessment protocols used in biosecurity and prioritising EDRR; 4) increasing our understanding of regime shifts based on a few well-studied systems (such as the case studies reviewed in this paper) to achieve a better mechanistic understanding of the relationships between species traits and social and environmental features, that could provide greater predictive understanding of invasiondriven regime shifts. This could be applied to identify species on the verge of tipping points to promote EDRR before thresholds or tipping points are reached. Furthermore, identifying and understanding statistical early warning signals of regime shifts in the context of invasiondriven regime shifts (Scheffer et al., 2009; Hui and Richardson, 2017), and developing tools to track these to facilitate rapid adaptive management of invasive alien species is needed (Scheffer et al., 2001, 2009).

\subsubsection{Impact reduction and reversal (post regime shift management)}

Once an invasion-related regime shift has occurred a number of options are available to manage it, including mechanical, chemical and biological control, control through utilisation, alteration of land-use practices, or a combination of these methods, each with their own benefits and costs (van Wilgen et al., 2011; Shackleton et al., 2017b). Once a regime shift has occurred, physical control or alteration to landuse practices are very unlikely to reverse wide-scale regime shifts and contain spread of the invasive (Bhagwat et al., 2012; van Wilgen et al., 2012; Shackleton et al., 2014). Nevertheless, such control measures can lessen social-ecological impacts and provide localised restoration successes in priority areas (e.g. effective manual control of $C$. odorata in the large Hluhluwe-iMfolozi Park, although surrounding areas outside of the nature reserve are still heavily invaded (te Beest et al., 2017)).

The one management approach that has successfully reversed shifts over large scales is the use of biological control which is often considered the most cost effective and sustainable long term management approach (McFadyen, 1998; Page and Lacey, 2006; van Wilgen and De Lange, 2011), as discussed in the case study of salvinia and water hyacinth in Papua New Guinea (Fig. 7) The wattle case study might be at the beginning of a regime shift reversal (after around 100 years), as biological control has greatly reduced seed production (van Wilgen et al., 2012), although there will be sustained invasions for long periods due to substantial seedbanks that have accumulated (Strydom et al., 2017). A number of other regime-shift-inducing invasive alien plants have been successfully controlled allowing the invaded systems to reverte back to their original regimes (e.g. several water weed species globally (McFadyen, 1998; Coetzee et al., 2011a, b; Julien et al., 2007; Hussner et al., 2017), Opuntia species in Australia, South Africa and the USA, (Goeden et al., 1967; Zimmermann and Moran, 1991), and Siam weed (C. odorata) in Indonesia, but not in other parts of the world (de Chenon et al., 2002; Julien et al., 2007; Zachariades et al., 2009; Day et al., 2013).

Despite some success in removing species that cause regime shifts, such control measures often give rise to other challenges. In some cases, removal of one invasive species facilitates opportunities for secondary invasions, as the disturbed systems are less resilient and a number of feedbacks can have long lasting legacy effects (Coetzee et al., 2011a). For example, changes in soil chemistry can persist for more than 10 years after wattle clearing and can facilitate secondary grass invasions and hinder the re-establishment of native species (Nsikani et al., 2017). In another case, submerged aquatic invasive species invaded after the successful management of invasive floating macrophytes (Coetzee et al., 2011b), apparently due to "invasional meltdown" - the interacting effects of multiple invasive species and the changes they cause (Simberloff and Von Holle, 1999).

Reversing and restoring all ecosystems that have undergone invasion-related regime shifts is not feasible. It is therefore important to the weigh costs of restoration against the costs of impacts associated with the shift. If the long-term costs of restoration exceed the projected costs created by the regime shift, other options should be considered, especially if the shift has negative impacts but also provides benefits for people or the environment. Although controversial (Murcia et al., 2014), in some cases adopting a "novel ecosystems" or a "social adaptation to reduce vulnerability" approach might be appropriate (Hobbs et al., 2006; Chapin et al., 2010; Hobbs et al., 2009; Kannan et al., 2014), possibly along with focused and well-prioritised smallscale management in some areas. Novel ecosystems are areas that have 
been abandoned, disturbed or invaded by alien species, where the abiotic and biotic characteristics have been altered to such an extent that returning the system to some historical condition is extortionately expensive or impossible (Hobbs et al., 2009; Graham et al., 2014). Adopting a novel ecosystem approach implies living with, and adapting to, a new self-sustaining social-ecological regime (Morse et al., 2014). For example, because of the poor success with control efforts against L.camara in India (Bhagwat et al., 2012), some communities have adapted to using this species for weaving, a common local livelihood practice in southern India. In this case, they have no other choice but to make the best of the situation (Kannan et al., 2014). Similar novel ecosystem management approaches have been suggested for Nile perch, focusing on social innovations or adaptations (see Mazigo, 2017) that can strengthen resilience and reduce vulnerability of communities.

In the context of social-ecological systems, more nuanced understanding of different stakeholders and power dynamics (some benefiting from invasion at the expense of others) is crucial for improving governance of social-ecological systems that have undergone regime shifts. Promoting engagement between different stakeholders can help reduce conflicts, improve social learning and aid successful collaborative governance (Novoa et al., 2018; Shackleton et al., 2018a, 2018b). Improving prioritization, undertaken in a collaborative manner, of areas and species for management based on their social and ecological effects is also a key need. A variety of tools are available to support such work (Forsyth et al., 2012; Shackleton et al., 2017b; Bacher et al., 2018; Potgieter et al., 2018), but there is also a need to develop additional tools that take a broader social-ecological perspective.

\section{Conclusions}

Invasive species are increasingly important drivers of regime shifts which have significant ecological and social impacts in many parts of the world. We have highlighted the value of holistic and integrated social-ecological systems thinking to understand the processes leading to these shifts and the overall effects that such shifts have on the environment and society. Using causal-loop diagrams and frameworks for elucidating ecosystem services and the dimensions of human wellbeing, we have drawn on four case studies to elaborate and compare the drivers and consequences of these shifts from a social-ecological systems perspective. We identified a diverse set of pathways underlying these shifts; these range from relatively simple pathways to highly complex processes resulting from the interaction of invasive species with many different drivers and feedbacks. The regime shifts we investigated all resulted in a diverse set of impacts on ecosystems, ecosystem services, livelihoods and human wellbeing. In some cases, regime shifts also resulted in benefits, leading to conflicts of interest between different stakeholders, and complexity around how to manage the invasive species. Identifying species that have the potential to generate highimpact regime shifts, understanding the diversity of consequences for different stakeholders, and developing robust management methods to reduce impacts and restore systems are key priorities for further research.

To improve our understanding and to facilitate adequate governance of regime shifts caused by invasive alien species we suggest six priority areas for research and policy development. 1) Further work is needed to better understand when and how invasive species can trigger regime shifts and how to recognize early warning signals of such regime shifts. 2) Insights on risks of invasive species causing regime shifts must be incorporated in risk-analysis protocols to improve biosecurity. 3) Perspectives from work on social-ecological systems must be better incorporated in invasion science through expanded inter- and transdisciplinary collaborations. 4) Collaborative governance and shared understanding between different actors to maximise the effectiveness of management interventions following regime shifts is crucial for promoting adaptive capacity and shared responsibility. 5) Biological control should be further promoted as a cost effective and sustainable way of managing invasive species to prevent and reduce impacts on humans and the environment. 6) Better strategies and models are needed to guide restoration following initial management interventions to increase system resilience, especially to prevent secondary invasions and to deal with long-lasting legacy effects.

\section{Acknowledgements}

We acknowledge funding from the DST-NRF Centre for Invasion Biology, the National Research Foundation of South Africa (grant 85417 to D.M.R.) and "Consolidoc" support from the office of the Vice Rector: Research, Innovation and Postgraduate Studies at Stellenbosch University to R.T.S. The work was also supported through a Social Sciences and Humanities Research Council of Canada (SSHRC) grant to B.M.H.L. R.B. received support from the South African Research Chairs Initiative (SARChI) of the Department of Science and Technology and National Research Foundation of South Africa (grant 98766); the Guidance for Resilience in the Anthropocene: Investments for Development (GRAID) project funded by the Swedish International Development Agency (Sida); and a Young Researchers Grant from the Vetenskapsrådet in Sweden (grant 621-2014-5137).

\section{References}

Abila, Richard O., Jansen, Eirik G., 1997. From local to global markets. The fish exporting and fishmeal industries of Lake Victoria: structure, strategies and socio-economic impacts in Kenya. IUCN Technical Report.

Adger, N., 2000. Social and ecological resilience: are they related? Prog. Hum. Geogr. 24 364-437.

Allsopp, N., Colville, J., Verboom, T. (Eds.), 2014. Fynbos: Ecology, Evolution and Conservation of a Megadiverse Region. Oxford University Press, Oxford.

Anagnostakis, S.L., 1982. Biological control of chestnut blight. Science 466-471.

Anagnostakis, S.L., 1987. Chestnut blight: the classical problem of an introduced pathogen. Mycologia 79, 23-37.

Andersen, T., Carstensen, J., Hernandez-Garcia, E., Duarte, C.M., 2009. Ecological thresholds and regime shifts: approaches to identification. Trends Ecol. Evol. (Amst.) 24, 49-57.

Anderson, C.B., Griffith, C.R., Rosemond, A.D., Rozzi, R., Dollenz, O., 2006. The effects of invasive North American beavers on riparian plant communities in Cape Horn, Chile: do exotic beavers engineer differently in sub-Antarctic ecosystems? Biol. Conserv. $128,467-474$.

Appleton, J., 2000. 'At my age I should be sitting under that tree.' the impact of AIDS on Tanzanian lakeshore communities. Gend. Dev. 2, 19-27.

Armitage, D.R., Plummer, R., Berkes, F., Arthur, R.I., Charles, A.T., Davidson-Hunt, I.J., Diduck, A.P., Doubleday, N.C., Johnson, D.S., Marschke, M., McConney, P., 2009. Adaptive co-management for social?ecological complexity. Fron. Ecol. Environ. 7 (2), 95-102.

Bacher, S., Blackburn, T.M., Essl, F., Genovesi, P., Heikkilä, J., Jeschke, J.M., Jones, G., Keller, R., Kenis, M., Kueffer, C., Martinou, A.F., Nentwig, W., Pergl, J., Pyšek, P., Rabitsch, W., Richardson, D.M., Roy, H.E., Saul, W.-C., Scalera, R., Vilà, M., Wilson, J.R.U., Kumschick, S., 2018. Socio-economic impact classification of alien taxa (SEICAT). Methods Ecol. Evol. 9, 159-168.

Balirwa, J.S., Chapman, C.A., Chapman, L.J., Cowx, I.G., Geheb, K., Kaufman, L., LoweMcConnell, R.H., Seehausen, O., Wanink, J.H., Welcomme, R.L., Witte, F., 2003 Biodiversity and fishery sustainability in the Lake Victoria basin: an unexpected marriage? Bioscience 53, 703-716.

Bennett, E.M., Cumming, G.S., Peterson, G.D., 2005. A systems model approach to determining resilience surrogates for case studies. Ecosystems 8, 945-957.

Berks, F., Colding, J., Folke, C., 2003. Navigating Social-ecological Systems: Building Resilience for Complexity and Change. Cambridge University Press, Cambridge.

Bhagwat, S.A., Breman, E., Thekaekara, T., Thornton, T.F., Willis, K.J., 2012. A battle lost or won? Report on two centuries of invasion and management of Lantana camara L. In Australia, India and South Africa. PLoS One 7, E32407.

Biggs, R., Carpenter, S.R., Brock, W.A., 2009. Turning back from the brink: detecting an impending regime shift in time to avert it. Proc. Natl. Acad. Sci. U. S. A. 106, 826-831.

Biggs, R., Blenckner, T., Folke, C., Gordon, L., Norström, A., Nyström, M., Peterson, G.D. 2012. Regime shifts. In: Hastings, A., Gross, L. (Eds.), Encyclopedia of Theoretical Ecology. University of California Press, Ewing, NJ, USA, pp. 609-617.

Biggs, R., Boonstra, W.J., Peterson, G.D., Schlüter, M., 2016. The domestication of fire as social-ecological regime shift. Past Global Changes 24, 22-23.

Biggs, R., Peterson, G.D., Rocha, J., 2018. The Regime Shifts Database: a framework for analysing regime shifts in social-ecological systems. Ecol. Soc. 23 (3), 9. https://doi. org/10.5751/ES-10264-230309.

Blackburn, T.M., Pyšek, P., Bacher, S., Carlton, J.T., Duncan, R.P., Jarošík, V., Wilson, J.R.U., Richardson, D.M., 2011. A proposed unified framework for biological invasions. Trends Ecol. Evol. (Amst.) 26, 333-339.

Blackburn, T.M., Essl, F., Evans, T., Hulme, P.E., Jeschke, J.M., Kühn, I., Kumschick, S., 
Marková, Z., Mrugała, A., Nentwig, W., Pergl, J., 2014. A unified classification of alien species based on the magnitude of their environmental impacts. PLoS Biol. 12, e1001850.

Blythe, J.L., 2014. Resilience and social thresholds in small-scale fishing communities. Sustain. Sci. 10, 157-165.

Boonstra, W.J., Björkvik, E., Haider, L.J., Masterson, V., 2016. Human responses to social -ecological traps. Sustain. Sci. 11, 877-889.

Brooks, M.L., D’Antonio, C.M., Richardson, D.M., Grace, J.B., Keeley, J.E., DiTomaso, J.M., Hobbs, R.J., Pellant, M., Pyke, D., 2004. Effects of invasive alien plants on fire regimes. BioScience 54, 677-688.

Brooks, N., Adger, W.N., Kelly, P.M., 2005. The determinants of vulnerability and adaptive capacity at the national level and the implications for adaptation. Glob. Environ. Change 15, 51-163.

Chaffin, B.C., Garmestani, A.S., Angeler, D.G., Herrmann, D.L., Stow, C.A., Nyström, M., Sendzimir, J., Hopton, M.E., Kolasa, J., Allen, C.R., 2016. Biological invasions, ecological resilience and adaptive governance. J. Environ. Manage. 183, 399-407.

Chapin III, F.S., Carpenter, S.R., Kofinas, G.P., Folke, C., Abel, N., Clark, W.C., Olsson, P., Smith, D.M.S., Walker, B., Young, O.R., Berkes, F., Biggs, R., Grove, M., Naylor, R.L., Pinkerton, E., Steffen, W., Swanson, F.J., 2010. Ecosystem stewardship: sustainability strategies for a rapidly changing planet. Trends Ecol. Evol. (Amst.) 25, 241-249.

Chytrý, M., Maskell, L.C., Pino, J., Pyšek, P., Vilà, M., Font, X., Smart, S.M., 2008. Habitat invasions by alien plants: a quantitative comparison among Mediterranean, subcontinental and oceanic regions of Europe. J. Appl. Ecol. 45, 448-458.

Clavero, M., García-Berthou, E., 2005. Invasive species are a leading cause of animal extinctions. Trends Ecol. Evol. (Amst.) 20, 110.

Coetzee, J.A., Hill, M.P., Byrne, M.J., Browns, A., 2011a. A review of the biological control programmes on Eichhornia crassipes (C. Mart.) Solms (Pontederiaceae), Salvinia molesta D.S.MItch. (Salviniaceae), Pistia stratiotes L. (Araceae), Myriophyllum aquaticum (Vell.) Verdc. (Haloragaceae) and Azolla filiculoides Lam. (Azollaceae) in South Africa. Afr. Entomol. 19, 451-568.

Coetzee, J.A., Bownes, A., Martin, G.D., 2011b. Prospects for the biological control of submerged macrophytes in South Africa. Afr. Entomol. 19, 469-487.

Crépin, A.S., Biggs, R., Polasky, S., Troell, M., Zeeuw, 2012. Regime shifts and management. Ecol. Econ. 84, 15-22.

Crooks, J.A., Soulé, M.E., Sandlund, O.T., 1999. Lag times in population explosions of invasive species: causes and implications. In: Sandlund, O.T., Schei, P.J., Viken, A. (Eds.), Invasive Species and Biodiversity Management. Kluwer Academic Publishers, Dordrecht, Netherlands, pp. 103-125.

Day, M.D., Bofeng, I., Nabo, I., 2013. Successful biological control of Chromolaena odorata (asteraceae) by the gall fly cecidochares connexa (diptera: tephritidae) in Papua New Guinea. Proceedings of the XIII International Symposium on Biological Control of Weeds.

de Chenon, R.D., Sipayung, A., Sudharto, P., 2002. A decade of biological control against Chromolaena odorata at the Indonesian oil Palm research institute in marihat. Proceedings of the $5^{\text {th }}$ International Workshop on Biological Control and Management of Chromolaena odorata.

de Neergaard, A., Saarnak, C., Hill, T., Khanyile, M., Berzosa, A.M., Birch-Thomsen, T., 2005. Australian wattle species in the Drakensberg region of South Africa-An invasive alien or a natural resource? Agric. Syst. 85, 216-233.

del Carmen Carrillo-Flota, E., Aguilar-Perera, A., 2017. Stakeholder perceptions of red lionfish (Pterois volitans) as a threat to the ecosystem and its potential for human consumption in Quintana roo, Mexico. Ocean Coast. Manage. 136, 113-119.

Diskin, M., Steiner, K.C., Hebard, F.V., 2006. Recovery of American chestnut character istics following hybridization and backcross breeding to restore blight-ravaged Castanea dentata. For. Ecol. Manage. 223, 439-447.

Downey, P.O., Richardson, D.M., 2016. Alien plant invasions and native plant extinctions: a six-threshold framework. AoB Plants plw047.

Downing, A.S., Galic, N., Goudswaard, K.P., van Nes, E.H., Scheffer, M., Witte, F., Mooij, W.M., 2013. Was Lates late? A null model for the Nile perch boom in Lake Victoria. PLoS One 8, e76847.

Downing, A.S., van Nes, E.H., Balirwa, J.S., Beuving, J., Bwathondi, P.O.J., Chapman, L.J., Cornelissen, I.J., Cowx, I.G., Goudswaard, K.P., Hecky, R.E., Janse, J.H., 2014. Coupled human and natural system dynamics as key to the sustainability of Lake Victoria's ecosystem services. Ecol. Soc. 19.

Drake, J.M., Lodge, D.M., 2004. Global hot spots of biological invasions: evaluating op tions for ballast-water management. Proc. R. Soc. Lond., B, Biol. Sci. 271, 575-580.

Early, R., Bradley, B.A., Dukes, J.S., Lawler, J.J., Olden, J.D., Blumenthal, D.M., Gonzalez, P., Grosholz, E.D., Ibañez, I., Miller, L.P., Sorte, C.J., 2016. Global threats from invasive alien species in the twenty-first century and national response capacities. Nat. Commun. 23, 7.

Ellison, Aaron M., Michael, S. Bank, Clinton, Barton D., Colburn, Elizabeth A., Elliott, Katherine, Ford, Chelcy R., Foster, David R., et al., 2005. Loss of foundation species: consequences for the structure and dynamics of forested ecosystems. Front. Ecol Environ. 3 (9), 479-486.

Essl, F., Bacher, S., Blackburn, T.M., et al., 2015a. Crossing frontiers in tackling pathways of biological invasions. BioScience 65, 769-782.

Essl, F., Dullinger, S., Rabitsch, R., Hulme, P.E., Pyšek, P., Wilson, J.R.U., Richardson, D.M., 2015b. Historical legacies accumulate to shape future biodiversity change. Divers. Distrib. 21, 534-547 doi: 0.1111/ddi.12312, 2015.

Essl, F., Hulme, P.E., Jeschke, J.M., Keller, R., Pyšek, P., Richardson, D.M., Saul, W.C., Bacher, S., Dullinger, S., Estévez, R.A., Kueffer, C., 2017. Scientific and normative foundations for the valuation of alien-species impacts: thirteen core principles. BioScience 67, 166-178.

Folke, C., 2006. Resilience: the emergence of a perspective for social-ecological systems analyses. Glob. Environ. Change 16, 253-267.

Folke, C., Carpenter, S., Walker, B., Scheffer, M., Elmqvist, T., Gunderson, L., Holling,
C.S., 2006. Regime shifts, resilience, and biodiversity in ecosystem management. Annu. Rev. Ecol. Evol. Syst. 35, 557-581.

Forsyth, G.G., David Le Maitre, C., O'farrell, P.J., Van Wilgen, B.W., 2012. The prioritisation of invasive alien plant control projects using a multi-criteria decision model informed by stakeholder input and spatial data. J. Environ. Manage. 103, 51-57.

Foxcroft, L.C., McGeoch, M., 2011. Implementing invasive species management in an adaptive management framework. Koedoe 53, 1006.

Freinkel, S., 2007. American Chestnut: the Life, Death and Rebirth of a Perfect Tree. University of California Press.

Gaertner, M., Holmes, P.M., Richardson, D.M., 2012. Biological invasions, resilience and restoration. In: van Andel, J., Aronson, J. (Eds.), Restoration Ecology - The New Frontier. Wiley-Blackwell, Oxford, pp. 265-280.

Gaertner, M., Biggs, R., Te Beest, M., Hui, C., Molofsky, J., Richardson, D.M., 2014 Invasive plants and drivers of regime shifts: identifying high-priority invaders that alter feedback relationships. Divers. Distrib. 20, 733-744.

Gaertner, M., Le Maitre, D.C., Esler, K.J., 2017. Alterations of disturbance regimes by plant and animal invaders. In: Vila, M., Hulme, P. (Eds.), Impact of Biological Invasions on Ecosystem Services. Springer, Cham.

Godfree, R., Firn, J., Johnson, S., Knerr, N., Stol, J., Doerr, V., 2017. Why non-native grasses pose a critical emerging threat to biodiversity conservation, habitat connectivity and agricultural production in multifunctional rural landscapes. Landsc. Ecol. 32, 1219-1242.

Goeden, R., Fleschner, C., Ricker, D., 1967. Biological Control of Prickly Pear cacti on Santa Cruz Island 38. California Agriculture, California, pp. 579-606.

Goudswaard, K.P., Witte, F., Katunzi, E.F., 2008. The invasion of an introduced predator, Nile perch (Lates niloticus, L.) in Lake Victoria (east Africa): chronology and causes. Environ. Biol. Fishes 81, 127-139.

Graham, N.A., Cinner, J.E., Norström, A.V., Nyström, M., 2014. Coral reefs as novel ecosystems: embracing new futures. Curr. Opin. Environ. Sustain. 7, 9-14.

Gravatt, G.F., 1949. Chestnut blight in Asia and North America. Unasylva 3, 3-7.

Hakansson, I., Skyllerstedt, S., Selling, N., Biggs, R., Rochar, J.C., Berg, H., 2012. Lake Victoria. http://regimeshifts.org/component/k2/item/408-lake-victoria\#.

Hammond, C., 2012. Impacts of Agriculturally-driven Regime Shifts on Ecosystem Services and Human Well-being. Master's Thesis. Stockholm Resilience Centre: Stockholm University.

Heiniger, U., Rigling, D., 1994. Biological control of chestnut blight in Europe. Annu. Rev. Phytopathol. 32, 581-599.

Hejda, M., Pyšek, P., Jarošík, V., 2009. Impact of invasive plants on the species richness, diversity and composition of invaded communities. J. Ecol. 97, 393-403.

Henderson, L., Wilson, J.R.U., 2017. Changes in the composition and distribution of alien plants in South Africa: an update from the Southern African Plant Invaders Atlas. Bothalia 47, a2172. https://doi.org/10.4102/abc.v47i2.2172.

Hobbs, R.J., Arico, S., Aronson, J., et al., 2006. Novel ecosystems: theoretical and management aspects of the new ecological world order. Glob. Ecol. Biogeogr. 15, 1-7.

Hobbs, R.J., Higgs, E., Harris, J.A., 2009. Novel ecosystems: implications for conservation and restoration. Trends Ecol. Evol. (Amst.) 24, 599-605.

Hughes, T.P., Carpenter, S., Rockström, J., Scheffer, M., Walker, B., 2013. Multiscale regime shifts and planetary boundaries. Trends Ecol. Evol. (Amst.) 28, 389-395.

Hui, C., Richardson, D.M., 2017. Invasion Dynamics. Oxford University Press, Oxford.

Hulme, P.E., 2009. Trade, transport and trouble: managing invasive species pathways in an era of globalization. J. Appl. Ecol. 46, 10-18.

Hussner, A., Stiers, I., Verhofstad, M.J.J.M., Bakker, E.S., Grutters, B.M.C., Haury, J., van Valkenburg, J.L.C.H., Brundu, G., Newman, J., Clayton, J.S., Anderson, L.W.J., 2017. Management and control methods of invasive alien freshwater aquatic plants: a review. Aquat. Bot. 136, 112-137.

Iannone, B.V., Potter, K.M., Guo, Q., Liebhold, A.M., Pijanowski, B.C., Oswalt, C.M., Fei, S., 2016. Biological invasion hotspots: a trait-based perspective reveals new sub-continental patterns. Ecography 39, 961-969.

Jacobs, D.F., 2007. Toward development of silvical strategies for forest restoration of American chestnut (Castanea dentata) using blight-resistant hybrids. Biol. Conserv. 137, 497-506.

Jeschke, J.M., Bacher, S., Blackburn, T.M., Dick, J.T., Essl, F., Evans, T., Gaertner, M., Hulme, P.E., Kühn, I., Mrugała, A., Pergl, J., Pyšek, P., Rabitsch, W., Ricciardi, A., Richardson, D.M., Sendek, A., Vilá, M., Winter, M., Kumschick, S., 2014. Defining the impact of non-native species. Conserv. Biol. 28, 1188-1194.

Johnson, J.L., 2010. From Mfangano to Madrid: the global commodity chain for kenyan nile perch. Aquat. Ecosyst. Health Manag. 13, 20-27.

Julien, M.H., Orapa, W., 1999. Structure and management of a successful biological control project for water hyacinth. Proceedings of the $1^{\text {st }}$ IOBC Global Working Group Meeting for the Biological and Integrated Control of Water Hyacinth 123-134.

Julien, M.H., Griffiths, M.W., Stanley, J.N., 2001. Biological Control of Water Hyacinth 2. ACIAR, Australia.

Julien, M.H., Scott, J.K., Orapa, W., Paynter, Q., 2007. History, opportunities and challenges for biological control in Australia, New Zealand and the Pacific islands. Crop. Prot. 26, 255-267.

Kannan, R., Shackleton, C.M., Shaanker, R.U., 2014. Invasive alien species as drivers in social-ecological systems: local adaptations towards use of Lantana in Southern India. Environ. Dev. Sustain. 16, 649-669.

Keller, R.P., Lodge, D.M., Finnoff, D.C., 2007. Risk assessment for invasive species produces net bioeconomic benefits. Proc. Natl. Acad. Sci. U. S. A. 104, 203-207.

Kinzig, A., Ryan, P., Etienne, M., Allison, H., Elmqvist, T., Walker, B., 2006. Resilience and regime shifts: assessing cascading effects. Ecol. Soc. 11.

Kueffer, C., 2013. Integrating natural and social sciences for understanding and managing plant invasions. In: Larrue, S. (Ed.), Biodiversity and Societies in the Pacific Islands. Presses Universitaires De Provence, Collection "Confluent Des Sciences" \& ANU Epress, pp. 71-96. 
Kueffer, C., 2017. Plant invasions in the anthropocene. Science 358, 724-725.

Kueffer, C., Kull, C.A., 2017. Non-native species and the aesthetics of nature. In: Hulme, P., Vilà, M., Ruiz, G. (Eds.), Impact of Biological Invasions on Ecosystem Services. Springer, Berlin, pp. 311-324.

Kueffer, C., Pyšek, P., Richardson, D.M., 2013b. Integrative invasion science: model systems, multi-site studies, focused meta-analysis, and invasion syndromes. New Phytol. 200, 615-633.

Kull, C.A., Shackleton, C.M., Cunningham, P.J., et al., 2011. Adoption, use and perception of Australian acacias around the world. Divers. Distrib. 175, 822-836.

Kull, C.A., Kueffer, C., Richardson, D.M., Vaz, A.S., Vicente, J.R., Honrado, J.P., 2018. Using the 'regime shift' concept in addressing social-ecological change. Geogr. Res. 56, 26-41. https://doi.org/10.1111/1745-5871.12267.

Lade, S.J., Tavoni, A., Levin, S.A., Schluter, M., 2013. Regime shifts in a social-ecological system. Theor. Ecol. 6, 359-372.

Le Maitre, D.C., Gaertner, M., Marchante, E., Ens, E.J., Holmes, P.M., Pauchard, A., O’Farrell, P.J., Rogers, A.M., Blanchard, R., Blignaut, J., Richardson, D.M., 2011. Impacts of invasive Australian acacias: implications for management and restoration. Divers. Distrib. 17, 1015-1029.

Le Maitre, D.C., Forsyth, G.G., Dzikiti, S., Gush, M.B., 2016. Estimates of the impacts of invasive alien plants on water flows in South Africa. Water Sa 42, 659-672.

Leadley, P., Proença, V., Fernández-Manjarrés, J., Pereira, H.M., Alkemade, R., Biggs, R., Bruley, E., Cheung, W., Cooper, D., Figueiredo, J., Gilman, E., 2014. Interacting regional-scale regime shifts for biodiversity and ecosystem services. BioScience 64 665-679.

Legg, J.P., Thresh, J.M., 2000. Cassava mosaic virus disease in East Africa: a dynamic disease in a changing environment. Virus Res. 71, 135-149.

Lesser, M.P., Slattery, M., 2011. Phase shift to algal dominated communities at mesophotic depth associated with lionfish (Pterois volitans) invasion on a Bahamian coral reef. Biol. Invasions 13, 1855-1868.

Linder, H.P., Lehmann, C.E.R., Archibald, S., Osborne, C., Richardson, D.M., 2018. Global grass (Poaceae) success underpinned by traits facilitating colonization, persistence and habitat transformation. Biol. Rev. 93, 1125-1144. https://doi.org/10.1111/brv. 12388.

LVFO, 2011. The Lake Victoria fisheries Organization. The Implementation of a Fisheries Management Plan (IFMP) Project.

Mack, M.C., D’Antonio, C.M., 1998. Impacts of biological invasion on disturbance regimes. Trends Ecol. Evol. (Amst.) 13, 195-198.

Mazigo, A.F., 2017. Promoting social innovation through action research: evidence from an empirical study in the fisheries sector of Ukerewe District in Tanzania. J. Human Dev. Capabil. 18, 239-257.

McCormick, F.J., Platt, R.B., 1980. Recovery of Appalachian forest following the chestnut blight or Catherine Keever - you were right!. Am. Midl. Nat. 104, 264-273.

McFadyen, R.E.C., 1998. Biological control of weeds. Annu. Rev. Entomol. 43, 369-393.

Meyerson, L.A., Reaser, J.K., 2002. Biosecurity: moving toward a comprehensive approach: a comprehensive approach to biosecurity is necessary to minimize the risk of harm caused by non-native organisms to agriculture, the economy, the environment, and human health. BioScience 52, 593-600.

Milgroom, M.G., Cortesi, P., 2004. Biological control of chestnut blight with hypovirulence: a critical analysis. Annu. Rev. Phytopathol. 42, 3111-3338.

Millennium Ecosystem Assessment (MA), 2005. Millennium Ecosystem Assessment: Ecosystems and Human Wellbeing: a Framework for Assessment. Island Press, Washington DC

Milton, S.J., Dean, W.R.J., Richardson, D.M., 2003. Economic incentives for restoring natural capital: trends in southern Africa rangelands. Front. Ecol. Environ. 1, 247-254.

Mitchell, D.S., Petr, T., Viner, A.B., 1980. The water fern Salvinia molesta in the Sepik River, Papua New Guinea. Environ. Conserv. 7, 115-122.

Molony, T., Richey, L.A., Sauper, H., 2007. Darwin's nightmare: a critical assessment. Rev. Afr. Pol. Ecol. 34, 598-608.

Morse, N.B., Pellissier, P.A., Cianciola, E.N., Brenton, R.L., Sullivan, M.M., Shonka, N.K., Wheeler, T.B., McDowell, W.H., 2014. Novel ecosystems in the Anthropocene: a revision of the novel ecosystem concept for pragmatic applications. Ecol. Soc. 19, 12.

Murcia, C., Aronson, J., Kattan, G.H., Moreno-Mateos, D., Dixon, K., Simberloff, D., 2014. A critique of the 'novel ecosystem' concept. Trends Ecol. Evol. (Amst.) 29, 548-553.

Novoa, A., Shackleton, R.T., Canavan, S., Cybéle, C., Davies, S.J., Dehnen-Schmutz, K. Fried, J., Gaertner, M., Geerts, S., Griffiths, C., Kaplan, H., Kumschick, S., Le Maitre, D.C., Measey, J., Nunes, A.L., Richardson, D.M., Robinson, T.B., Touza, J., Wilson, J.R.U., 2018. A framework for engaging stakeholders on the management of alien species. J. Environ. Manage. 205, 286-297.

Nsikani, M.M., Novoa, A., van Wilgen, B.W., Keet, J.H., Gaertner, M., 2017. Acacia saligna's soil legacy effects persist up to 10 years after clearing: implications for ecological restoration. Austral. Ecol. https://doi.org/10.1111/aec.12515.

Page, A.R., Lacey, K.L., 2006. Economic Impact Assessment of Australia Weed Biological Control. CRC for Australian Weed Management, Australia.

Pejchar, L., Mooney, H.A., 2009. Invasive species, ecosystem services and human wellbeing. Trends Ecol. Evol. (Amst.) 24, 497-504.

Polasky, S., Carpenter, S.R., Folke, C., Keeler, B., 2011. Decision-making under great uncertainty: environmental management in an era of global change. Trends Ecol. Evol. (Amst.) 26, 398-404.

Potgieter, L., Kueffer, C., Larson, B., Livingston, S., O'Farrell, P., Gaertner, M., Richardson, D.M., 2017. Alien plants as mediators of ecosystem services and disservices in urban systems: A global review. Biol. Invasions 19, 3571-3588. https://doi.org/10.1007/ s10530-017-1589-8.

Potgieter, L., Gaertner, M., Irlich, U.M., O’Farrell, P.J., Stafford, L., Vogt, H., Richardson, D.M., 2018. Managing urban plant invasions: a multi-scale prioritization framework. Environ. Manage. https://doi.org/10.1007/s00267-018-1088-4. (in press).
Rhoades, C.C., 2006. The influence of American Chestnut (Castanea dentata) on nitrogen availability, organic matter and chemistry of silty and sandy loam soils. Pedobiologica 50, 553-562.

Richardson, D.M., Cowling, R.M., 1992. Why is mountain fynbos invasible and which species invade? In: Van Wilgen, B.W., Richardson, D.M., Kruger, F.J., van Hensbergen, H.J. (Eds.), Fire in South African Mountain Fynbos. Springer-Verlag, Berlin, pp. 161-181.

Richardson, D.M., Cowling, R.M., Lamont, B.B., 1996. Non-linearities, synergisms and plant extinctions in South African fynbos and Australian kwongan. Biodivers. Conserv. 5, 1035-1046.

Richardson, D.M., Pyšek, P., Carlton, J.T., 2011. A compendium of essential concepts and terminology in invasion ecology. In: Richardson, D.M. (Ed.), Fifty Years of Invasion Ecology. The Legacy of Charles Elton. Wiley-Blackwell, Oxford, pp. 409-420.

Rocha, J., Yletyinen, J., Biggs, R., Blenckner, T., Peterson, G., 2015. Marine regime shifts: drivers and impacts on ecosystems services. Philos. Trans. R. Soc. B 37020130273.

Rouget, M., Robertson, M.P., Wilson, J.R., Hui, C., Essl, F., Renteria, J.L., Richardson, D.M., 2016. Invasion debt-Quantifying future biological invasions. Divers. Distrib. $22,445-456$.

Scheffer, M., Carpenter, S.R., 2003. Catastrophic regime shifts in ecosystems: linking theory to observation. Trends Ecol. Evol. (Amst.) 18, 648-656.

Scheffer, M., Carpenter, S.R., Foley, J.A., Folke, C., Walker, B., 2001. Catastrophic shifts in ecosystems. Nature 413, 591-596.

Scheffer, M., Bascompte, J., Brock, W.A., Brovkin, V., Carpenter, S.R., Dakos, V., Held, H., Van Nes, E.H., Rietkerk, M., Sugihara, G., 2009. Early-warning signals for critical transitions. Nature 461, 53.

Schüttler, E., Rozzi, R., Jax, K., 2011. Towards a societal discourse on invasive species management: a case study of public perceptions of mink and beavers in Cape Horn. J. Nat. Conserv. 19, 175-184.

Seebens, H., et al., 2017. No saturation in the accumulation of alien species worldwide. Nat. Commun. 8, 14435.

Seehausen, O., van Alphen, J.M., Witte, F., 1997. Cichlid fish diversity threatened by eutrophication that curbs sexual selection. Science 277, 1808-1811.

Shackleton, C.M., McGarry, D., Fourie, S., Gambiza, J., Shackleton, S.E., Fabricius, C., 2007. Assessing the effect of invasive alien species on rural livelihoods: case examples and a framework from South Africa. Hum. Ecol. 35, 113-127.

Shackleton, R.T., Le Maitre, D.C., Pasiecznik, N.M., Richardson, D.M., 2014. Prosopis: a global assessment of the biogeography, benefits, impacts and management of one of the world's worst woody invasive plant taxa. AoB Plants 6 plu027.

Shackleton, R.T., Witt, A.B.R., Nunda, W., Richardson, D.M., 2017a. Chromolaena odorata (Siam weed) in eastern Africa: distribution and socio-ecological impacts. Biol. Invasions 19, 1285-1298.

Shackleton, R.T., Le Maitre, D.C., van Wilgen, B.W., Richardson, D.M., 2017b. Towards a national strategy to optimise the management of a widespread invasive tree (Prosopis species; mesquite) in South Africa. Ecosyst. Serv. 27, 242-252. https://doi.org/10. 1016/j.ecoser.2016.11.022.

Shackleton, R.T., Shackleton, C.M., Kull, C.A., 2018a. The role of invasive alien species in shaping local livelihoods and human well-being. J. Environ. Manage. https://doi. org/10.1016/j.jenvman.2018.05.007.

Shackleton, R.T., Adriaens, T., Brundu, G., Dehnen-Schmutz, K., Estevez, R., Fried, J., Larson, B.M.H., Lui, S., Marchante, E., Merchante, H., Moshobane, M., Novoa, A., Reed, M., Richardson, D.M., 2018b. Stakeholder engagement in the study and management of invasive alien species: a review. J. Environ. Manage. https://doi.org/10 1016/j.jenvman.2018.04.044. (in press).

Sharma, O.P., Raghubanshi, A.S., Singh, J.S., 2005. Lantana invasion: an overview. Weed Biol. Manag. 5, 157-165.

Shin-ichiro, S.M., Usio, N., Takamura, N., Washitani, I., 2009. Contrasting impacts of invasive engineers on freshwater ecosystems: an experiment and meta-analysis. Oecologia 158, 673-686.

Simberloff, D., Von Holle, B., 1999. Positive interaction of nonindigenous species: inversional meltdowns? Biol. Invasions 1, 21-32.

Smock, L.A., MacGregor, C.M., 1988. Impact of the American chestnut blight on aquatic shredding macroinvertebrates. J. North Am. Benthol. Soc. 7, 212-221.

Souza-Alonso, P., Rodríguez, J., González, L., Lorenzo, P., 2017. Here to stay. Recent advances and perspectives about Acacia invasion in Mediterranean areas. Ann. For. Sci. https://doi.org/10.1007/s13595-017-0651-0.

Strydom, M., Veldtman, R., Ngwenya, M.Z., Esler, K.J., 2017. Invasive Australian Acacia seed banks: size and relationship with stem diameter in the presence of gall-forming biological control agents. PLoS One 12, e0181763.

Swallow, B., 2009. Tradeoffs, synergies and traps among ecosystem services in the Lake Victoria basin of East Africa. Environ. Sci. Policy 12, 504-519.

te Beest, M., Howison, O., Howinson, R., Dew, L.A., Poswa, M.M., Dumalisile, L., Janse van Rensburg, S., Terblanche, C., 2017. Successful control of the invasive shrub Chromolaena odorata in hluhluwe-iMfolozi park. In: Cromsight, J.P.G.M., Archibald, S., Owen-Smith, N. (Eds.), Conserving Africa'S Megadiversity in the Anthropocene. University Press, Cambridge, Cambridge, pp. 358-382.

Thomas, P.A., Room, P.M., 1985. Towards biological control of salvinia in Papua New Guinea. Proceedings of the VI Symposium on Biological Control of Weeds.

van Wilgen, B.W., De Lange, W.D., 2011. The costs and benefits of biological control of invasive alien plants in South Africa. Afr. Entomol. 19, 504-514.

van Wilgen, B.W., Wannenburgh, A., 2016. Co-facilitating invasive species control, water conservation and poverty relief: achievements and challenges in South Africa's working for Water programme. Curr. Opin. Environ. Sustain. 19, 7-17.

van Wilgen, B.W., Dyer, C., Hoffmann, J.H., Ivey, P., Le Maitre, D.C., Moore, J.L., Richardson, D.M., Rouget, M., Wannenburgh, A., Wilson, J.R., 2011. National-scale strategic approaches for managing introduced plants: insights from Australian acacias in South Africa. Divers. Distrib. 17, 1060-1075. 
van Wilgen, B.W., Forsyth, G.G., Le Maitre, D.C., Wannenburgh, A., Kotzé, J.D., van den Berg, E., Henderson, L., 2012. An assessment of the effectiveness of a large, nationalscale invasive alien plant control strategy in South Africa. Biol. Conserv. 148, 28-38.

Vaz, A.S., Kueffer, C., Kull, C.A., Richardson, D.M., Vicente, J.R., Kühn, I., Schröter, M., Hauck, J., Bonn, A., Honrado, J.P., 2017a. Integrating ecosystem services and disservices: insights from plant invasions. Ecosyst. Serv. 23, 94-107.

Vaz, A.S., Kueffer, C., Kull, C.A., Richardson, D.M., Schindler, S., Muñoz-Pajares, A.J., Vicente, J.R., Martins, J., Hui, C., Kühn, I., Honrado, J.P., 2017b. The progress of interdisciplinarity in invasion science. Ambio 46, 428-442.

Walker, B., Holling, C.S., Carpenter, S.R., Kinzig, A., 2004. Resilience, adaptability and transformability in social-ecological systems. Ecol. Soc. 9, 5.

Wilson, J.R., Ivey, P., Manyama, P., Nanni, I., 2013. A new national unit for invasive species detection, assessment and eradication planning. South Afr. J. Sci. 109 (5/6). https://doi.org/10.1590/sajs.2013/20120111.

Witte, F., Silsbe, G.M., Hecky, R.E., Goudswaard, P.C., Guildford, S.J., Kishe-Machumu,
M.A., Wanink, J.H., 2012. Did the loss of phytoplanktivorous fish contribute to algal blooms in the Mwanza Gulf of Lake Victoria? Hydrobiologia 679, 283-296.

Woodford, D.J., Richardson, D.M., MacIsaac, H.J., Mandrak, N.E., Van Wilgen, B.W., Wilson, J.R.U., Weyl, O.L.F., 2016. Confronting the wicked problem of managing biological invasions. NeoBiota 31, 63.

Zachariades, C., Day, M., Muniappan, R., Reddy, G.V.P., 2009. Chromolaena odorata (L.) King and robinson (asteraceae). In: Muniappan, R., Reddy, G.V.P., Raman, A. (Eds.), Biological Control of Tropical Weeds Using Arthropods. University Press, Cambridge, Cambridge, pp. 130-162.

Zengeya, T., Ivey, P., Woodford, D.J., Weyl, O., Novoa, A., Shackleton, R., Richardson, D., van Wilgen, B., 2017. Managing conflict-generating invasive species in South Africa: Challenges and trade-offs. Bothalia-Afr. Biodivers. Conserv. 47 (2), 1-11.

Zimmermann, H.G., Moran, V.C., 1991. Biological control of prickly pear, Opuntia ficusindica (Cactaceae), in South Africa. Agric. Ecosyst. Environ. 37, 29-35. 